\title{
Interactions of monensin with dietary fat and carbohydrate components on ruminal fermentation and production responses by dairy cows ${ }^{1}$
}

\author{
B. Mathew, M. L. Eastridge, ${ }^{2}$ E. R. Oelker, J. L. Firkins, and S. K. R. Karnati \\ Department of Animal Sciences, The Ohio State University, Columbus 43210
}

\begin{abstract}
Variation in milk fat percentage resulting from monensin supplementation to lactating dairy cows could be due to altered ruminal fermentation with interactions of monensin with ruminal biohydrogenation of fat and ruminal carbohydrate availability. The objective of the study was to determine the effects of feeding monensin as Rumensin ( $\mathrm{R}$ ) in diets differing in starch availability (ground or steam-flaked corn), effective fiber (long or short alfalfa hay, LAH or SAH), and $4 \%$ fat (F) from distillers grains, roasted soybeans, and an animal-vegetable blend on ruminal fermentation characteristics and milk production in lactating dairy cows. Six ruminally cannulated lactating Holstein cows were used in a balanced $6 \times 6$ Latin square design with 21 -d periods. The cows were fed 6 diets: (1) $\mathrm{C}=$ control diet with ground corn and LAH, (2) $\mathrm{CR}=\mathrm{C}$ plus R, (3) CRFL $=\mathrm{CR}$ plus $\mathrm{F}$, (4) CRFS = ground corn, R, F, and $\mathrm{SAH}$, (5) SRFL = steam-flaked corn, R, F, and LAH, and (6) SRFS = steam-flaked corn, R, F, and SAH. Mean particle size of LAH was $5.00 \mathrm{~mm}$ and $1.36 \mathrm{~mm}$ for SAH. All diets were formulated to have $21 \%$ forage NDF and $40 \%$ NFC. The R tended to decrease DMI, decreased milk fat yield, and numerically lowered milk fat percentage (3.41 vs. $2.98 \%$ ). Addition of $\mathrm{F}$ to $\mathrm{R}$ diets did not affect milk fat percentage. By feeding diets containing $\mathrm{R}$ and $\mathrm{F}$, SAH tended to increase milk fat percentage for the ground-corn diet, but SAH tended to decrease milk fat percentage with steam-flaked corn (CRFL + SRFS vs. CRFS + SRFL). The steam-flaked corn increased total-tract NDF digestibility (CRFL + CRFS vs. SRFL + SRFS; 51.1 vs. $56 \%$ ). Addition of $\mathrm{F}$ with $\mathrm{R}$ decreased total VFA concentration and increased rumen $\mathrm{pH}$. Fat addition with $\mathrm{R}$ decreased rumen $\mathrm{NH}_{3} \mathrm{~N}$ and MUN (12.8 vs. $13.9 \mathrm{mg} / \mathrm{dL}$ ), and SFC
\end{abstract}

\footnotetext{
Received June 30, 2010.

Accepted September 14, 2010.

${ }^{1}$ Research was supported by state and federal funds appropriated to the Ohio Agricultural and Development Center, The Ohio State University. Manuscript number 3580. Additional support was provided by Elanco Animal Health, Greenfield, IN.

${ }^{2}$ Corresponding author: eastridge.1@osu.edu
}

decreased $\mathrm{NH}_{3} \mathrm{~N}$ concentration compared with ground corn. Although R caused milk fat depression, addition of $\mathrm{F}$ did not further exacerbate milk fat depression. Fatty acid analysis did not implicate any particular biohydrogenation intermediate as the causative factor for the milk fat depression.

Key words: corn processing, dietary fat, monensin, particle size

\section{INTRODUCTION}

Monensin, an ionophore antibiotic, has been approved for use in lactating dairy cows to improve feed efficiency. Monensin administration to lactating dairy cattle has several potential benefits, which include improved energy metabolism, increased milk production, and reduced incidence of subclinical and clinical ketosis, ruminal acidosis, and abomasal displacement (McGuffey et al., 2001). Feeding monensin to dairy cows has been implicated in milk fat depression (MFD), but this response was found to be inconsistent (Duffield et al., 2003). This variation in milk fat percentage response when feeding monensin might be due to alterations in rumen microbial processes with interactions of monensin with ruminal biohydrogenation (BH) of fat and ruminal carbohydrate availability. The variation in milk fat percentage from feeding monensin might be influenced by interactions with certain dietary factors (Duffield et al., 2008). These dietary factors could include unsaturated fat, effective fiber, and starch availability, which could be additive or might interact with respect to risk for MFD.

We hypothesized that the addition of monensin would depress milk fat concentration and alter the milk fatty acid (FA) profile, possibly by inhibiting the last step of $\mathrm{BH}$, leading to an accumulation of FA isomers causing MFD. The addition of unsaturated fat to diets already containing monensin would further depress milk fat concentration, possibly by providing more substrate for the production of specific $\mathrm{BH}$ intermediates. A combination of steam-flaked corn and low effective fiber in the diets, along with supplemental fat and monensin, could exacerbate MFD by reducing ruminal $\mathrm{pH}$ and adversely affecting ruminal fermentation, leading to disruption of 
the BH pathways. The objectives of this study were to evaluate the effects of adding monensin in diets differing in supplemental fat, starch availability, and effective fiber on ruminal fermentation characteristics and production in lactating dairy cows. Another objective was to test for potential interactions between particle size and corn processing in diets containing monensin and supplemental fat on milk components, particularly milk fat.

\section{MATERIALS AND METHODS}

\section{Animals, Treatments, and Experimental Design}

Six ruminally cannulated lactating Holstein cows were used in a $6 \times 6$ balanced Latin square design, each period lasting $3 \mathrm{wk}$, with the last week being used for sampling and data collection. Care and handling of the animals were conducted as outlined in the guidelines of The Ohio State University Institutional Animal Care and Use Committee. At the start of the trial, the cows were $194 \pm 64$ DIM; thus, cows were in late lactation at the conclusion of the study. The cows were housed individually in a conventional tiestall barn, with automatic waterers. The cows were milked twice daily at 0500 and 1700 h. Posilac (synthetic bST, Monsanto, St. Louis, MO) injections were given every 2 wk throughout the trial.

Treatment diets consisted of 50\% forage and $50 \%$ concentrates on a DM basis (Table 1). The forage consisted of alfalfa hay and corn silage. The experimental diets contained either ground corn or steam-flaked corn as sources of starch. Each period, the cows were fed 1 of 6 diets: (1) $\mathbf{C}=$ control diet with ground corn and long-particle-size alfalfa hay $(\mathbf{L A H}),(2) \mathbf{C R}=\mathrm{C}$ plus $12 \mathrm{~g} / 909 \mathrm{~kg}$ DM of monensin as Rumensin (R), (3) $\mathbf{C R F L}=$ CR plus $4 \%$ added fat (F), (4) CRFS $=$ ground corn, $\mathrm{R}, \mathrm{F}$, and short-particle-size alfalfa hay (SAH), (5) SRFL = steam-flaked corn, R, F, and LAH, and (6) SRFS = steam-flaked corn, R, F, and SAH. The $4 \%$ supplemental $\mathrm{F}$ diets included dried distillers grains with solubles, roasted soybeans, and animal-vegetable fat blend, replacing dried distillers grains, soybean meal, and soybean hulls in the diets having a basal amount of fat $(\mathrm{C}$ and $\mathrm{CR})$. This method of introducing unsaturated $\mathrm{F}$ was expected to represent normal industry practices. Rumensin (monensin sodium, Elanco Animal Health, Greenfield, IN) was added to all experimental diets except for the control diet at $12 \mathrm{~g} / \mathrm{t}$ of TMR on a DM basis. The $\mathrm{R}$ was added as a premix to the concentrate, with ground corn as the carrier. Between periods, ruminal contents were transferred to the next cow receiving that treatment to facilitate microbial adaptation to $\mathrm{R}$.
Steam-flaked corn was provided by Pennfield Feeds (Lancaster, PA). The steam-flaked corn had a flake density of $321 \mathrm{~g} / \mathrm{L}$, according to the manufacturer's specifications. The measured flake density of the steam-flaked corn was $441 \mathrm{~g} / \mathrm{L}$. The flake density was measured in the laboratory only after the end of the trial and so the higher flake density might have been due to moisture loss and crumbling due to storage. The corn silage (36.7\% DM, 8.2\% CP, and 40.5\% NDF) was from the same harvest, and the alfalfa hay $(91.0 \%$ DM, $20.8 \%$ $\mathrm{CP}$, and $36.4 \% \mathrm{NDF}$ ) was from large rectangular bales set aside from the same harvest. The SAH was obtained by using a commercial hay chopper (Patz model 9427 stationary bale chopper, Pound, WI), and the LAH was obtained using a TMR mixer wagon (Roto-Mix Forage Express model 274-12B, Dodge City, KS).

Mean particle size of dried alfalfa hay was determined using a portable sieve shaker (W.S. Tyler Inc., Gastonia, NC) fitted with USA standard testing sieves with varying mesh sizes of $9.50,4.75,2.36,1.18,0.600$, and $0.300 \mathrm{~mm}$. Arithmetic mean particle size was calculated as described by Murphy and Zhu (1997). Mean particle size and particle size distribution of the TMR samples composited by period were determined using a Penn State particle separator as described by Kononoff et al. (2003). The mean particle sizes of the SAH and LAH, as determined by the laboratory sieve shaker, were 1.36 and $5.00 \mathrm{~mm}$, respectively. The mean particle size of the corn silage as determined by the laboratory sieve shaker was $7.73 \mathrm{~mm}$. The particle size measurements on the forages were done on an as-is basis.

The experimental diets were individually mixed once daily in a stationary mixer, and the TMR were fed twice daily in equal proportions. Orts were weighed daily at $1600 \mathrm{~h}$ to adjust feed offered for 10\% refusal. The TMR composition was adjusted weekly based on $\mathrm{DM}$ percentage of the corn silage determined at $55^{\circ} \mathrm{C}$.

\section{Sampling Schedule}

Daily feed intake was recorded throughout the trial. Feed offered was sampled once daily on d 15 through 18 of each period, and $10 \%$ of the orts was sampled on d 16 through 19 of each period. The TMR and orts samples were composited by period and dried at $55^{\circ} \mathrm{C}$.

Nutrient digestibility was determined using chromic oxide as a digestibility marker. The chromic oxide pellets were composed of $90 \%$ soybean hulls and $10 \%$ chromic oxide. The pellets were dosed through the rumen cannula twice daily on d 8 through 18 of each period at $1 \%$ of dietary DM. Fecal grab samples were taken on $\mathrm{d} 7$ of each period to account for background levels of chromium. Fecal grab samples were taken on d 16 to 19 of each period so that every $3 \mathrm{~h}$ in a 24 -h period 
Table 1. Ingredient composition of dietary treatments

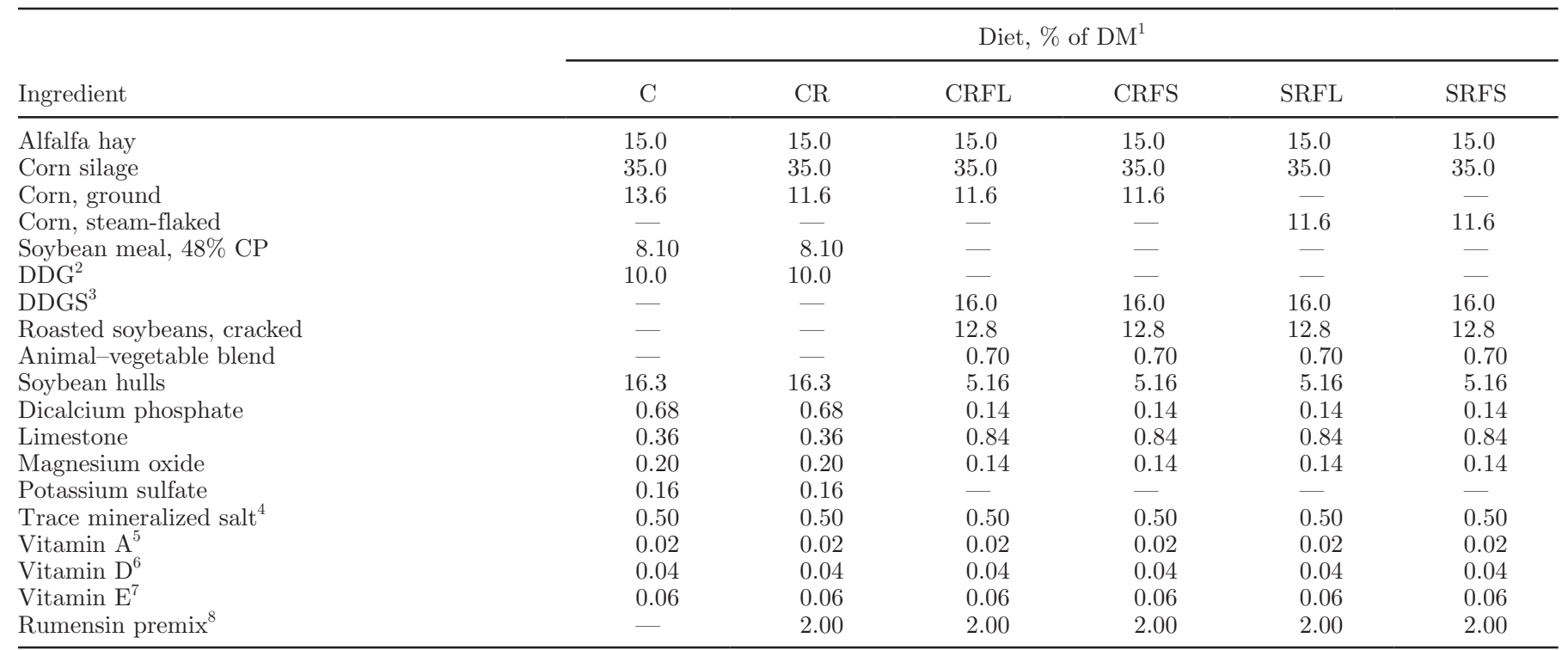

${ }^{1} \mathrm{C}=$ control diet containing ground corn and long particle size of alfalfa hay (LAH); CR = C plus $12 \mathrm{~g} / \mathrm{t}$ TMR DM of monensin as Rumensin $(\mathrm{R}) ; \mathrm{CRFL}=$ ground corn, $4 \%$ added fat $(\mathrm{F}), \mathrm{R}$, and LAH; CRFS = ground corn, $\mathrm{R}, \mathrm{F}$, and short particle size of alfalfa hay $(\mathrm{SAH}) ; \mathrm{SRFL}=$ steam-flaked corn, R, F, and LAH; and SRFS = steam-flaked corn, R, F, and SAH.

${ }^{2}$ Dried distillers grains (Dakota Gold HP, Poet Nutrition).

${ }^{3}$ Dried distillers grains with solubles (Dakota Gold, Poet Nutrition, Sioux Falls, SD).

${ }^{4}$ Contained $0.10 \% \mathrm{Mg} ; 38.0 \% \mathrm{Na} ; 58.0 \% \mathrm{Cl} ; 0.04 \% \mathrm{~S} ; 5,000 \mathrm{mg}$ of Fe/kg; 7,500 mg of Zn/kg; 2,500 mg of Cu/kg; $6,000 \mathrm{mg}$ of Mn/kg; $100 \mathrm{mg}$ of $\mathrm{I} / \mathrm{kg} ; 60 \mathrm{mg}$ of $\mathrm{Se} / \mathrm{kg}$; and $50 \mathrm{mg}$ of $\mathrm{Co} / \mathrm{kg}$.

${ }^{5}$ Contained 30,000 IU of vitamin $\mathrm{A} / \mathrm{g}$.

${ }^{6}$ Contained 3,000 IU of vitamin D/g.

${ }^{7}$ Contained $44 \mathrm{IU}$ of vitamin E/g.

${ }^{8}$ Elanco Animal Health, Greenfield, IN (initially formulated to provide $12 \mathrm{~g}$ of monensin/909 $\mathrm{kg}$ of total dietary DM; based on analysis of the premix, provided $14 \mathrm{~g} / 909 \mathrm{~kg}$ ).

were represented (total of 8 samples per period). Fecal samples were dried in a forced-air oven at $40^{\circ} \mathrm{C}$ and composited by cow within period.

Representative grab samples of ruminal contents were removed at $0,3,6$, and $9 \mathrm{~h}$ after feeding on $\mathrm{d}$ 18 and 19 of each period. A subsample of the ruminal contents was strained through 4 layers of cheesecloth, and the $\mathrm{pH}$ of the ruminal fluid was taken immediately. A $50 \mathrm{~mL}$ aliquot of the filtered rumen fluid was acidified with $3 \mathrm{~mL}$ of $6 \mathrm{~N} \mathrm{HCl}$ and frozen at $-20^{\circ} \mathrm{C}$ until further analysis. The 2 samples within each time point were composited.

Ruminal contents were completely evacuated 2 $\mathrm{h}$ before feeding on $\mathrm{d} 20$ and $2 \mathrm{~h}$ after feeding on $\mathrm{d}$ 21 of each period to determine pool size of nutrients. The total ruminal contents were separated into solid and liquid fractions using a hydraulic wine press. The solid and liquid fractions were weighed separately. A $1 \%$ subsample (by weight) of the solid fraction and a $1 \%$ subsample of the liquid fraction were reconstituted to a representative sample and stored at $-20^{\circ} \mathrm{C}$ until further analysis. The remaining ruminal contents were returned to the cow. After thawing, the reconstituted rumen samples were composited by cow within period and lyophilized to determine DM content. The liquid fraction was subsampled to obtain a $25-\mathrm{mL}$ aliquot of fluid, which was fixed with $25 \mathrm{~mL}$ of $50 \%$ formalin to preserve protozoa. The protozoal samples were stored at room temperature.

Milk yields were recorded at each milking. Milk samples were taken for 4 consecutive milkings on d 17 to 19 of each period, and each sample was divided into 2 aliquots. One aliquot was analyzed for fat, protein, lactose, and MUN by DHI Cooperative, Inc. (Columbus, $\mathrm{OH})$. The second aliquot was stored at $-20^{\circ} \mathrm{C}$ for FA analysis. Milk component percentages were weighted for the amount of milk per milking.

Individual BW of the cows were measured weekly after the a.m. milking and were averaged per period. The BCS of individual cows was assessed at the beginning of the trial and at the end of each period (Edmonson et al., 1989). 


\section{Laboratory Analyses}

Samples of feed offered, orts, fecal contents, and ruminal contents were ground to pass through a 1-mm screen (Wiley Mill, Arthur H. Thomas, Philadelphia, PA). Chromic oxide pellets were ground manually using a mortar and pestle. Samples of feed offered, orts, and fecal contents were analyzed for DM, OM, and N (AOAC, 1990). The NDF and ADF concentrations of feed offered, orts and fecal contents were analyzed using a Ankom 200 fiber analyzer (Ankom Technology, Macedon, NY) based on procedures described by Van Soest et al. (1991) using heat-stable $\alpha$-amylase and sodium sulfite. The samples were pretreated with acetone to remove fat. The NDIN and ADIN were determined by analyzing $\mathrm{N}$ concentrations of the NDF and ADF residues, respectively. The acid detergent lignin concentration of the TMR samples was analyzed sequentially after ADF analysis (Robertson and Van Soest, 1981). Chromic oxide pellets and fecal contents were analyzed for $\mathrm{Cr}$ by atomic absorption spectroscopy (Williams et al., 1962). Feed offered was analyzed for mineral concentrations using inductively coupled plasma emission spectrometry by the Ohio State University STAR laboratory (Wooster, $\mathrm{OH}$ ).

The particle size distribution of the TMR was determined using the Penn State particle separator, using 3 sieves: 19.0, 8.0, and $1.18 \mathrm{~mm}$ (Kononoff et al., 2003). Physical effectiveness factor (pef) was calculated as the proportion of particles retained on the $1.18-\mathrm{mm}$ screen (Mertens, 1997). Individual pef values for each screen $\left(\operatorname{pef}_{19.0}\right.$, pef $_{8.0}$, and pef $\left._{1.18}\right)$ also was calculated as the proportion of particles retained on the respective screens, which were multiplied by the respective NDF concentrations of particles in individual screens to obtain peNDF ${ }_{19.0}, \operatorname{peNDF}_{8.0}$, and peNDF ${ }_{1.18}$ values.

The acidified rumen fluid samples were thawed, centrifuged at $15,000 \times g$ at $4^{\circ} \mathrm{C}$ for $15 \mathrm{~min}$, and filtered through Whatman \#1 filter paper. The supernatant was analyzed for VFA concentrations by GLC (Harvatine et al., 2002a) and for concentration of $\mathrm{NH}_{3} \mathrm{~N}$ (Chaney and Marbach, 1962).

Feed offered, orts, and fecal contents were analyzed for starch using an enzymatic procedure utilizing heatstable $\alpha$-amylase and amyloglucosidase (M. B. Hall, US Dairy Forage Research Center, Madison, WI, personal communication). The glucose in the starch assay was analyzed colorimetrically using glucose oxidase-peroxidase (Karkalas, 1985). The procedure with modifications was provided by Mathew (2008).

The FA concentrations of feed offered and orts were determined using the 1-step methylation method of Palmquist and Jenkins (2003). A 2-step methylation procedure, utilizing $0.5 \mathrm{M}$ sodium methoxide (10 min at $\left.50^{\circ} \mathrm{C}\right)$ and $5 \%$ methanolic $\mathrm{HCl}\left(10 \mathrm{~min}\right.$ at $\left.80^{\circ} \mathrm{C}\right)$ was used to determine FA in ruminal contents, fecal contents, and milk (Ribeiro et al., 2005). Nonadecanoic acid was used as the internal standard. The FA methyl esters were analyzed by GLC (HP 5890 Series II; Hewlett Packard, Palo Alto, CA) using a $100-\mathrm{m} \times 0.25-\mathrm{mm}$ i.d., $0.2-\mu \mathrm{m}$ thickness SP-2560 fused silica capillary column (Supelco, Bellefonte, PA). Helium was used as the carrier gas, with a flow rate of $0.54 \mathrm{~mL} / \mathrm{min}$. The signal was detected by a flame ionization detector using hydrogen and air as oxidants and helium as the make-up gas. The flow rates for air, hydrogen and make-up helium were set at 430, 30 and $30 \mathrm{~mL} / \mathrm{min}$, respectively. The injector and flame ionization detector temperatures were set at $240^{\circ} \mathrm{C}$ and $245^{\circ} \mathrm{C}$, respectively, and the split ratio was set at 105:1.

For the feed offered and orts, the oven temperature was set for $140^{\circ} \mathrm{C}$ for $5 \mathrm{~min}$, increased by $4^{\circ} \mathrm{C} / \mathrm{min}$ to $230^{\circ} \mathrm{C}$ and held for $20 \mathrm{~min}$, decreased by $20^{\circ} \mathrm{C} / \mathrm{min}$ to $140^{\circ} \mathrm{C}$, and held for $1 \mathrm{~min}$. The total run time was 53 min. For the ruminal and fecal contents, the oven temperature was set for $60^{\circ} \mathrm{C}$ for $5 \mathrm{~min}$, increased by $3^{\circ} \mathrm{C} /$ min to $165^{\circ} \mathrm{C}$ and held for $10 \mathrm{~min}$, increased by $5^{\circ} \mathrm{C} /$ min to $230^{\circ} \mathrm{C}$, and held for $17 \mathrm{~min}$. The total run time for this temperature program was $80 \mathrm{~min}$.

The milk samples were analyzed using a combination of GC isothermal and temperature-gradient programs (Kramer et al., 2008). The isothermal temperature program was utilized to get improved separation of the 18:1 milk FA isomers. The temperature-gradient program used was the same as that used for analysis of ruminal and fecal contents as described previously. For the isothermal program run, the oven temperature was set for $45^{\circ} \mathrm{C}$ for $4 \mathrm{~min}$, increased by $13^{\circ} \mathrm{C} / \mathrm{min}$ to $162^{\circ} \mathrm{C}$ and held for $37 \mathrm{~min}$, increased by $4^{\circ} \mathrm{C} / \mathrm{min}$ to $215^{\circ} \mathrm{C}$, and held for $20 \mathrm{~min}$. The total run time for this isothermal program was $83.25 \mathrm{~min}$.

The results were quantified using Agilent ChemStation software (Rev. A.01.10; Agilent Technologies, Wilmington, DE). Fatty acid peaks were identified by comparing retention time with reference standards (FIMFAME-7, GLC-100, Matreya Inc., Pleasant Gap, PA; UC-59M, UC-60M, UC-61M, Nu-Chek Prep Inc., Elysian, MN).

Milk samples were analyzed by DHI Cooperative, Inc. for concentrations of fat, protein, and lactose using infrared spectroscopy (B2000 infrared analyzer, Bentley Instruments, Chaska, MN) and MUN using a Skalar SAN Plus segmented flow analyzer (Skalar Inc., Norcross, GA).

Indigestible NDF (INDF) concentration of the feed offered, orts, and ruminal samples was determined by 120-h in vitro fermentation (Dado and Allen, 1995). The INDF passage rate was calculated according to 
Harvatine et al. (2002b) using the following equation: INDF $k_{\mathrm{p}}\left(\mathrm{h}^{-1}\right)=$ (INDF intake/ruminal INDF pool size) $/ 24$.

Biohydrogenation was calculated based on the assumption that total FA intake was equal to ruminal FA outflow, according to Fievez et al. (2007), and expressing $\mathrm{FA}$ intake relative to the total intake of $\mathrm{C}_{18} \mathrm{FA}$. Biohydrogenation was calculated based on the above assumption and using the equation according to Tice et al. (1994).

\section{Statistical Analyses}

Data were analyzed as a Latin square design with cow as a random effect, using PROC MIXED of SAS (version 9.1.3; SAS Institute, 2004). The following model was used for the statistical analyses:

$$
\mathrm{Y}_{\mathrm{ijk}}=\mu+\mathrm{D}_{\mathrm{i}}+\mathrm{P}_{\mathrm{j}}+\mathrm{c}_{\mathrm{k}}+\mathrm{e}_{\mathrm{ijk}}
$$

where $Y_{\mathrm{ijk}}=$ the dependent variable, $\mu$ = overall mean, $D_{i}=$ fixed effect of diet, $P_{j}=$ fixed effect of period, $c_{k}$ $=$ random effect of cow, and $\mathrm{e}_{\mathrm{ijk}}=$ residual error .

Preplanned orthogonal contrasts were used to compare treatment means. The contrasts included (1) effect of $\mathrm{R}$ addition ( $\mathrm{C}$ vs. $\mathrm{CR}$ ), (2) effect of $\mathrm{F}$ addition with $\mathrm{R}$ (CR vs. CRFL), (3) the main effect of corn processing method (CRFL+ CRFS vs. SRFL + SRFS), (4) the main effect of hay particle size (CRFL+SRFL vs. CRFS+ SRFS), and (5) interaction of corn processing method and hay particle size (CRFL+SRFS vs. CRFS+SRFL).

The $\mathrm{pH}, \mathrm{VFA}$, and $\mathrm{NH}_{3} \mathrm{~N}$ measurements were analyzed as repeated measures. Repeated measures were analyzed using PROC MIXED, and the most appropriate covariance structure was determined by Bayesian information criterion. Diet $\times$ time interactions were evaluated and when interactions for diet by time were not deemed to be significant $(P>0.10)$, the averages over all time points were reported. Significant differences were declared at $P \leq 0.05$ and a trend at $P \leq$ 0.10 .

\section{RESULTS AND DISCUSSION}

Diet ingredient composition and chemical composition are presented in Tables 1 and 2, respectively. The $\mathrm{C}$ and $\mathrm{CR}$ diets had a higher NDF concentration because of the added $4 \% \mathrm{~F}$ diluted NDF concentrations in the F-supplemented diets and because of the higher concentration of soybean hulls in these diets. The FA percentage of the added-F diets (CRFL, CRFS, SRFL, and SRFS) were, on an average, $3.7 \%$ higher than that of the diets containing no supplemental F (C and $\mathrm{CR}$ ). The FA composition of the experimental diets is shown in Table 2 . The $4 \%$ added $\mathrm{F}$ diets had higher proportions of 18:0, cis-9 18:1, and total 18:1 FA. The proportions of 18:2 (n-6), 18:2 (n-3) and total unsaturated FA also were higher in the added-F diets.

The geometric mean particle length and particle length distribution of the experimental diets determined using the Penn State particle separator are shown in Table 3. As anticipated, the diets containing SAH had lower proportion of particles retained on the 19.0- $\mathrm{mm}$ screen compared with the diets with LAH. The diets with SAH also had greater proportions of particles less than $1.18 \mathrm{~mm}$. These observations were reflective of differences in the mean particle length of the SAH and $\mathrm{LAH}$. The mean particle size of the SAH as determined by the laboratory sieve-shaker was $1.36 \mathrm{~mm}$ and the mean particle size of the LAH was $5.00 \mathrm{~mm}$. Steamflaking increased the proportion of particles retained on the 8.0-mm screen. Diets containing steam-flaked corn also had a lower proportion of particles less than $1.18 \mathrm{~mm}$ compared with the ground corn diets. The geometric mean particle length of the steam-flaked corn diets was higher than that of the ground-corn diets. The geometric mean particle length of the diets containing SAH was lower compared with the diets containing $\mathrm{LAH}$. As planned, the pef of the diets containing SAH was lower than the diets containing LAH as a higher proportion of the diets containing SAH passed through the 1.18-mm sieve compared with the diets with LAH. The peNDF of the particles in the top screen was lower in the diets containing $\mathrm{SAH}$, whereas the peNDF of the particles in the bottom screen was lower in the diets containing LAH. The peNDF of particles greater than $1.18 \mathrm{~mm}$ were affected by steam-flaking, with the steam-flaked corn diets having a higher peNDF than the ground corn diets. As expected, the peNDF of particles greater than $1.18 \mathrm{~mm}$ was lower for the diets containing SAH compared with the diets with LAH. Yang and Beauchemin (2006) also suggested that dietary pef and peNDF vary with particle size of the forage and concentrate and also grain processing. However, they observed that the peNDF determined using the top 2 screens $(19.0$ and $8.0 \mathrm{~mm}$ ) is more reflective of particle size effects on chewing time and rumen $\mathrm{pH}$ than using the top 3 screens $(>1.18 \mathrm{~mm}$ ).

The addition of $\mathrm{R}$ did not affect ruminal $\mathrm{pH}$ (Table 4). Compared with the $\mathrm{CR}$ diet, the addition of $\mathrm{F}$ in the CRFL diet increased $(P=0.03)$ ruminal $\mathrm{pH}$. This increase in ruminal $\mathrm{pH}$ was reflective of a corresponding decrease in total VFA concentration (120 vs. $107 \mu M$ for CR and CRFL, respectively). Molar percentage of acetate was similar among diets. The $\mathrm{R}$ also increased 
Table 2. Chemical composition of dietary treatments

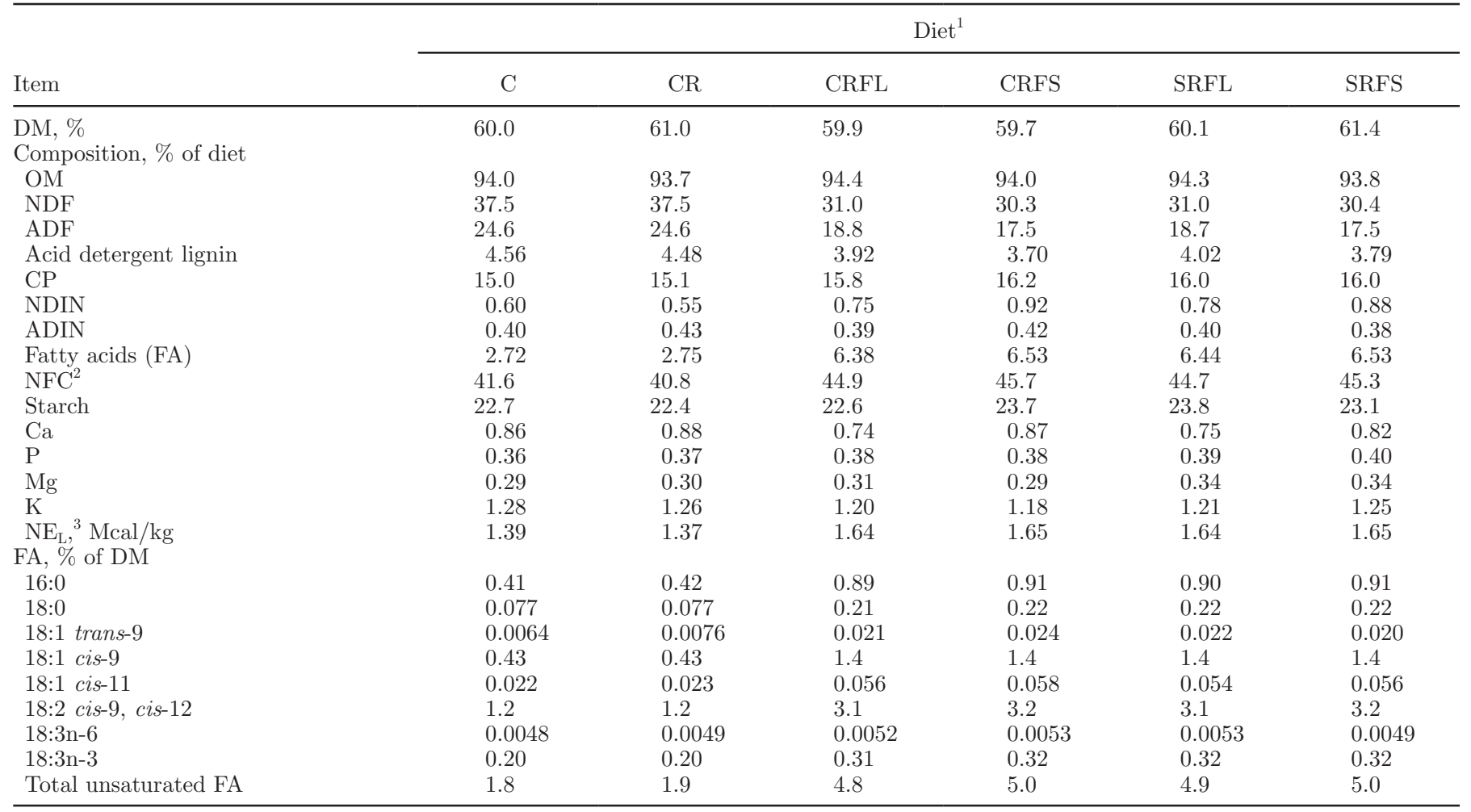

${ }^{1} \mathrm{C}=$ control diet containing ground corn and long particle size of alfalfa hay (LAH); CR = C plus $12 \mathrm{~g} / \mathrm{t}$ of TMR DM of monensin as Rumensin $(\mathrm{R}) ; \mathrm{CRFL}=$ ground corn, $4 \%$ added fat $(\mathrm{F}), \mathrm{R}$, and LAH; CRFS $=$ ground corn, R, F, and short particle size of alfalfa hay $(\mathrm{SAH}) ; \mathrm{SRFL}=$ steam-flaked corn, R, F, and LAH; and SRFS = steam-flaked corn, R, F, and SAH.

${ }^{2}$ Calculated as $100 \%-[(\mathrm{NDF}-\mathrm{NDICP})+\mathrm{CP}+$ ash $+(\mathrm{FA}+1)]$, where NDICP is neutral-detergent insoluble $\mathrm{CP}$, and FA +1 approximates ether extract (NRC, 2001).

${ }^{3}$ Calculated using NRC (2001) equations.

molar percentage of isobutyrate $(P<0.06)$ and isovalerate $(P<0.01)$, whereas it decreased molar percentage of valerate $(P=0.05)$. The addition of $\mathrm{F}$ with $\mathrm{R}$ tended to decrease valerate $(P=0.10)$, whereas it decreased $(P=0.01)$ the molar percentage of isovalerate. Steam-flaking decreased ruminal concentration of isobutyrate $(P<0.01)$ and tended to decrease ruminal concentration of isovalerate $(P=0.08)$.

The $\mathrm{R}$ had no effect on ruminal $\mathrm{NH}_{3} \mathrm{~N}$ (Table 4). Yang and Russell (1993) have reported reduced $\mathrm{NH}_{3} \mathrm{~N}$ concentration with $\mathrm{R}$ in vitro, possibly caused by inhibition of the growth of hyper-ammonia producing bacteria. The acetate:propionate ratio was not affected by the addition of $\mathrm{R}$, and all treatments resulted in an acetate:propionate ratio exceeding 2.5. This is in contrast to several studies where $\mathrm{R}$ supplementation decreased acetate:propionate (Sauer et al., 1998; Broderick, 2004). Addition of $\mathrm{F}$ with $\mathrm{R}$ decreased ruminal $\mathrm{NH}_{3} \mathrm{~N}$ concentration. Fat supplementation has resulted in either a decrease or no effect on rumen $\mathrm{NH}_{3} \mathrm{~N}$ concentration (Doreau and Ferlay, 1995). However, Elliott et al. (1997) reported increased ruminal $\mathrm{NH}_{3} \mathrm{~N}$ concen- trations with unsaturated $\mathrm{F}$. The decrease in $\mathrm{NH}_{3} \mathrm{~N}$ concentration with added $\mathrm{F}$ in our study may have been due to the replacement of soybean meal with roasted soybeans in the F-supplemented diets. Steam-flaking tended to decrease ruminal $\mathrm{NH}_{3} \mathrm{~N}$ concentration $(P=$ $0.09)$. The effect of increasing starch fermentability on $\mathrm{NH}_{3} \mathrm{~N}$ concentration has been observed in previous studies (Harvatine et al., 2002a; Bernard et al., 2004). The decline in ruminal $\mathrm{NH}_{3} \mathrm{~N}$ concentration could be due to increased utilization of $\mathrm{NH}_{3} \mathrm{~N}$ by ruminal microorganisms as a result of more readily available carbohydrate or increased RUP from steam-flaked corn, or both. The addition of $\mathrm{F}$ to $\mathrm{R}$ diets decreased rumen pool size of wet ruminal digesta, mainly by affecting pool size of rumen fluid (Table 4). No changes in INDF passage rates were observed.

The $\mathrm{R}$ did not affect the total numbers of protozoa or generic distribution of protozoa in rumen fluid (Table 5). A study by Guan et al. (2006) reported that protozoa adapted to $\mathrm{R}$ and that the protozoal populations recover within 3 to $5 \mathrm{wk}$ after initial suppression. The addition of $\mathrm{F}$ to $\mathrm{R}$ diets tended $(P=0.06)$ to increase 
Table 3. Least squares means of particle length distribution of the experimental diets supplemented with monensin and fat, and varying in starch availability and hay particle size

\begin{tabular}{|c|c|c|c|c|c|c|c|c|c|c|c|c|}
\hline \multirow[b]{2}{*}{ Item } & \multicolumn{6}{|c|}{ Diet $^{1}$} & \multirow[b]{2}{*}{ SEM } & \multicolumn{5}{|c|}{ Contrast $^{2}$} \\
\hline & $\mathrm{C}$ & $\mathrm{CR}$ & CRFL & CRFS & SRFL & SRFS & & $\mathrm{R}$ & $\mathrm{F}$ & $\mathrm{CP}$ & PS & $\mathrm{CP} \times \mathrm{PS}$ \\
\hline$>19.0 \mathrm{~mm}$ & 7.17 & 7.33 & 6.83 & 1.33 & 6.67 & 1.17 & 0.773 & 0.88 & 0.65 & 0.83 & $<0.01$ & 1.00 \\
\hline $19.0-8.0 \mathrm{~mm}$ & 23.0 & 22.0 & 24.0 & 24.0 & 29.2 & 29.7 & 1.26 & 0.58 & 0.27 & $<0.01$ & 0.84 & 0.84 \\
\hline $8.0-1.18 \mathrm{~mm}$ & 37.7 & 37.2 & 36.3 & 35.2 & 36.8 & 39.0 & 1.91 & 0.85 & 0.76 & 0.27 & 0.80 & 0.39 \\
\hline$<1.18 \mathrm{~mm}$ & 32.3 & 33.3 & 33.0 & 39.7 & 27.3 & 30.5 & 1.24 & 0.58 & 0.85 & $<0.01$ & $<0.01$ & 0.17 \\
\hline peNDF $_{8.0}, \%$ of DM & 11.3 & 10.8 & 10.8 & 9.5 & 11.7 & 11.6 & 0.61 & 0.52 & 0.98 & 0.02 & 0.26 & 0.33 \\
\hline peNDF $_{118},{ }^{6} \%$ of DM & 11.9 & 11.6 & 9.4 & 10.4 & 9.4 & 11.3 & 0.64 & 0.73 & 0.02 & 0.46 & 0.03 & 0.52 \\
\hline peNDF $_{>1.18}, \%$ of DM & 27.4 & 26.8 & 24.1 & 20.6 & 25.0 & 23.6 & 0.70 & 0.51 & 0.01 & 0.01 & $<0.01$ & 0.16 \\
\hline $\mathrm{X}_{\mathrm{gm}},{ }^{7} \mathrm{~mm}$ & 3.50 & 3.47 & 3.48 & 2.81 & 4.00 & 3.44 & 0.126 & 0.88 & 0.99 & $<0.01$ & $<0.01$ & 0.68 \\
\hline
\end{tabular}

${ }^{1} \mathrm{C}=$ control diet containing ground corn and long particle size of alfalfa hay (LAH); CR = C plus $12 \mathrm{~g} / \mathrm{t}$ of TMR DM of monensin as Rumensin $(\mathrm{R}) ; \mathrm{CRFL}=$ ground corn, $4 \%$ added fat $(\mathrm{F}), \mathrm{R}$, and LAH; CRFS = ground corn, $\mathrm{R}, \mathrm{F}$, and short particle size of alfalfa hay $(\mathrm{SAH})$; SRFL $=$ steam-flaked corn, R, F, and LAH; and SRFS = steam-flaked corn, R, F, and SAH.

${ }^{2} \mathrm{R}=$ Effect of monensin addition (C vs. $\mathrm{CR}$ ); $\mathrm{F}=$ effect of fat addition with monensin ( $\mathrm{CR}$ vs. CRFL); $\mathrm{CP}=$ main effect of corn processing method (CRFL+CRFS vs. SRFL+SRFS); PS = main effect of hay particle size (CRFL+SRFL vs. CRFS+SRFS); and CP $\times$ PS $=$ interaction of corn processing method and hay particle size (CRFL+SRFS vs. CRFS+SRFL).

${ }^{3}$ pef $=$ Physical effectiveness factor determined as the proportion of particles $\geq 1.18 \mathrm{~mm}$.

${ }^{4} \mathrm{peNDF}_{19.0}$ measured as the NDF concentration of the particles retained on the top screen $(>19.0 \mathrm{~mm})$ multiplied by the proportion of particles retained.

${ }^{5} \mathrm{peNDF}_{8.0}$ measured as the NDF concentration of the particles retained on the middle screen $(19.0-8.0$ mm $)$ multiplied by the proportion of particles retained on the screen.

${ }^{6}$ peNDF $_{1.18}$ measured as the NDF concentration of the particles retained on the bottom screen $(8.0-1.18$ mm $)$ multiplied by the proportion of particles retained on the screen.

${ }^{7} \mathrm{X}_{\mathrm{gm}}=$ geometric mean length of particles (as-is basis).

Table 4. Least squares means for ruminal fermentation characteristics and rumen pool sizes for dairy cows fed monensin in diets varying in supplemental fat, starch availability, and hay particle size

\begin{tabular}{|c|c|c|c|c|c|c|c|c|c|c|c|c|}
\hline Item & \multicolumn{6}{|c|}{$\operatorname{Diet}^{1}$} & SEM & \multicolumn{5}{|c|}{ Contrast $^{2}$} \\
\hline Ruminal pH & 5.85 & 5.86 & 6.04 & 5.99 & 5.98 & 5.94 & 0.06 & 0.91 & 0.03 & 0.32 & 0.41 & 0.87 \\
\hline Acetate (A) & 62.5 & 61.3 & 62.1 & 61.5 & 61.6 & 61.5 & 1.03 & 0.12 & 0.29 & 0.64 & 0.46 & 0.62 \\
\hline Propionate $(\mathrm{P})$ & 23.6 & 24.2 & 23.4 & 23.4 & 24.0 & 24.0 & 1.33 & 0.51 & 0.43 & 0.43 & 0.99 & 0.95 \\
\hline Valerate & 1.53 & 1.42 & 1.32 & 1.35 & 1.34 & 1.34 & 0.06 & 0.05 & 0.10 & 0.93 & 0.76 & 0.67 \\
\hline Isovalerate & 1.60 & 1.91 & 1.66 & 1.53 & 1.48 & 1.49 & 0.07 & $<0.01$ & 0.01 & 0.08 & 0.30 & 0.27 \\
\hline $\mathrm{A}: \mathrm{P}$ & 2.73 & 2.57 & 2.71 & 2.71 & 2.60 & 2.60 & 0.19 & 0.22 & 0.29 & 0.26 & 0.98 & 0.97 \\
\hline $\mathrm{NH}_{3} \mathrm{~N}, \mathrm{mg} / \mathrm{dL}$ & 7.29 & 8.03 & 6.12 & 7.06 & 5.27 & 5.79 & 0.64 & 0.36 & 0.04 & 0.09 & 0.22 & 0.71 \\
\hline \multicolumn{13}{|l|}{ Rumen pool size } \\
\hline Wet digesta, kg & 87.4 & 87.5 & 77.9 & 82.3 & 81.1 & 80.5 & 3.54 & 0.99 & 0.04 & 0.82 & 0.52 & 0.42 \\
\hline DM, \% & 18.2 & 18.6 & 19.0 & 20.0 & 19.6 & 19.4 & 0.66 & 0.55 & 0.57 & 0.94 & 0.50 & 0.31 \\
\hline
\end{tabular}

${ }^{1} \mathrm{C}=$ control diet containing ground corn and long particle size of alfalfa hay (LAH); $\mathrm{CR}=\mathrm{C}$ plus $12 \mathrm{~g} / \mathrm{t}$ of TMR DM of monensin as Rumensin $(\mathrm{R}) ; \mathrm{CRFL}=$ ground corn, $4 \%$ added fat $(\mathrm{F}), \mathrm{R}$, and LAH; CRFS = ground corn, R, F, and short particle size of alfalfa hay $(\mathrm{SAH}) ; \mathrm{SRFL}=$ steam-flaked corn, R, F, and LAH; and SRFS = steam-flaked corn, R, F, and SAH.

${ }^{2} \mathrm{R}=$ Effect of monensin addition ( $\mathrm{C}$ vs. $\mathrm{CR}$ ); $\mathrm{F}=$ effect of fat addition with monensin ( $\mathrm{CR}$ vs. CRFL); $\mathrm{CP}=$ main effect of corn processing method (CRFL+CRFS vs. SRFL+SRFS); PS = main effect of hay particle size (CRFL+SRFL vs. CRFS+SRFS); and CP $\times$ PS $=$ interaction of corn processing method and hay particle size (CRFL+SRFS vs. CRFS+SRFL).

${ }^{3}$ Rumen fluid $=$ wet digesta - DM.

${ }^{4}$ Rumen fluid $=$ rumen liquid separated from solid rumen contents using a winepress.

${ }^{5}$ INDF passage rate = indigestible NDF passage rate, calculated using equation according to Harvatine et al. (2002b). 
Table 5. Least squares means of protozoal counts in rumen contents of dairy cows fed monensin in diets varying in supplemental fat, starch availability, and hay particle size

\begin{tabular}{|c|c|c|c|c|c|c|c|c|c|c|c|c|}
\hline \multirow[b]{2}{*}{ Item } & \multicolumn{6}{|c|}{ Diet $^{1}$} & \multirow[b]{2}{*}{ SEM } & \multicolumn{5}{|c|}{ Contrast $^{2}$} \\
\hline & $\mathrm{C}$ & $\mathrm{CR}$ & CRFL & CRFS & SRFL & SRFS & & $\mathrm{R}$ & $\mathrm{F}$ & $\mathrm{CP}$ & PS & $\mathrm{CP} \times \mathrm{PS}$ \\
\hline \multirow[t]{2}{*}{ Total cells $/ \mathrm{mL}, \times 10^{6}$} & 0.71 & 0.87 & 1.15 & 0.81 & 0.96 & 0.98 & 0.08 & 0.15 & 0.06 & 0.95 & 0.13 & 0.07 \\
\hline & \multicolumn{6}{|c|}{$\%$ of total } & & & & & & \\
\hline Entodinium & 93.3 & 92.6 & 93.3 & 94.1 & 94.0 & 93.2 & 1.17 & 0.63 & 0.64 & 0.92 & 0.99 & 0.47 \\
\hline Epidinium & 5.04 & 6.13 & 4.81 & 3.82 & 3.97 & 4.62 & 0.91 & 0.35 & 0.26 & 0.98 & 0.83 & 0.32 \\
\hline Dasytricha & 0.28 & 0.62 & 1.02 & 0.74 & 0.92 & 1.51 & 0.33 & 0.40 & 0.34 & 0.24 & 0.58 & 0.14 \\
\hline
\end{tabular}

${ }^{1} \mathrm{C}=$ control diet containing ground corn and long particle size of alfalfa hay (LAH); $\mathrm{CR}=\mathrm{C}$ plus $12 \mathrm{~g} / \mathrm{t}$ of TMR DM of monensin as Rumensin $(\mathrm{R}) ; \mathrm{CRFL}=$ ground corn, $4 \%$ added fat $(\mathrm{F}), \mathrm{R}$, and LAH; CRFS $=$ ground corn, R, F, and short particle size of alfalfa hay $(\mathrm{SAH}) ; \mathrm{SRFL}=$ steam-flaked corn, R, F, and LAH; and SRFS = steam-flaked corn, R, F, and SAH.

${ }^{2} \mathrm{R}=$ effect of monensin addition (C vs. CR); $\mathrm{F}=$ effect of fat addition with monensin ( $\mathrm{CR}$ vs. CRFL); CP = main effect of corn processing method (CRFL+CRFS vs. SRFL+SRFS); PS = main effect of hay particle size $(\mathrm{CRFL}+\mathrm{SRFL}$ vs. $\mathrm{CRFS}+\mathrm{SRFS})$; and $\mathrm{CP} \times \mathrm{PS}=$ interaction of corn processing method and hay particle size (CRFL+SRFS vs. CRFS+SRFL).

total protozoal counts. The reason for this is not clear but could be a result of compounding toxicity. The effects of dietary $\mathrm{F}$ on protozoal counts have been variable. Karnati et al. (2009) reported higher total protozoal counts with animal-vegetable $\mathrm{F}$ compared with feeding no F, R, or bromoethanesulfonate in continuous cultures. However, Oldick and Firkins (2000) reported that $\mathrm{F}$ decreased total ruminal protozoa counts. In a study by Mendoza et al. (1993), the addition of tallow and $\mathrm{R}$ to the diets fed to sheep resulted in reduced protozoal numbers. In the current study, inhibition of protozoa by added $\mathrm{F}$ might have been less severe because the source of $\mathrm{F}$ (a combination of mainly roasted soybeans and distillers dried grains with solubles) would have a slower release of oil compared with free oil used in some studies. No treatment effects on the generic distribution of protozoa were observed.

In rumen contents, $\mathrm{R}$ decreased proportions of total short and medium chain FA isomers (Table 6). Although these FA are often the focus for determining effects on milk FA synthesis, the concentrations of trans-10 18:1 and trans-11 18:1 isomers were not affected by $\mathrm{R}$ treatment. The R increased concentrations of trans-12 18:1, trans-15 18:1 and trans-16/cis- 14 18:1. These increases in 18:1 isomers suggest that $\mathrm{R}$ disrupted the complete BH of unsaturated FA. Fellner et al. (1997) reported that $\mathrm{R}$ increased the proportions of cis and trans 18:1 FA in ruminal cultures. Jenkins et al. (2003) reported increased total trans 18:1 with $\mathrm{R}$ diets. In the current study, the $\mathrm{R}$ treatment did not affect concentrations of cis-9, trans-11 CLA or trans-10, cis-12 CLA. The trans-10, cis-12 CLA is one of the specific FA isomers that has been implicated in causing MFD. However, it has been reported that changes in trans-10, cis-12 CLA are sometimes inadequate to completely account for reduction in milk fat in diet-induced MFD (Perfield et al., 2006). Hence, other unique BH intermediates may be responsible for causing MFD (Peterson et al., 2003), which might have been the case in the present study. The $\mathrm{R}$ tended to increase ruminal concentrations of trans-11, cis-15 18:2 isomer, which is formed during the intermediate steps of $\mathrm{BH}$ of 18:3 n-3, involving group A and group B biohydrogenating bacteria (Harfoot and Hazlewood, 1997). Hence, the addition of $\mathrm{R}$ might have inhibited these microorganisms, tending to an accumulation of trans-11, cis-15 18:2.

The addition of $\mathrm{F}$ decreased the proportions of total short and medium chain FA and increased total trans 18:1 concentrations in ruminal digesta (Table 6). The addition of $2 \% \mathrm{~F}$ from extruded soybeans also showed a similar FA profile in rumen digesta (AbuGhazaleh et al., 2002) compared with F addition in our study. Jenkins et al. (2003) studied interactions between $\mathrm{R}$ and $5 \%$ soybean oil on ruminal FA concentrations in vitro. They reported higher trans 18:1 concentrations for a combination of $\mathrm{R}$ and $5 \%$ soybean oil, compared with $\mathrm{R}$ alone. Fat addition to diets already containing $\mathrm{R}$ also increased cis-9 18:1 concentration in rumen contents in our trial. Fat addition increased concentration of cis-9, trans-11 CLA but did not affect trans-10, cis-12 CLA concentration. The concentration of total long-chain $\mathrm{FA}>20 \mathrm{C}$ were decreased with $\mathrm{F}$ addition.

By design, the addition of $\mathrm{F}$ increased the total FA intake (Table 7). Fat addition to $\mathrm{R}$ diets resulted in an increase of total unsaturated FA intake. The diets with added $\mathrm{F}$ resulted in an average total unsaturated FA intake of $993 \mathrm{~g} / \mathrm{d}$ compared with $395 \mathrm{~g} / \mathrm{d}$ in the control and control plus $\mathrm{R}$ diets. Treatment did not affect the extent of BH. Fellner et al. (1997) reported that R disrupted $\mathrm{BH}$ in vitro due to decreased 18:0 and increased 
Table 6. Least squares means of fatty acid (FA) concentrations (\% of total FA) in rumen contents of dairy cows fed monensin in diets varying in supplemental fat, starch availability, and hay particle size

\begin{tabular}{|c|c|c|c|c|c|c|c|c|c|c|c|c|}
\hline \multirow[b]{2}{*}{ FA } & \multicolumn{6}{|c|}{$\operatorname{Diet}^{1}$} & \multirow[b]{2}{*}{ SEM } & \multicolumn{5}{|c|}{ Contrast $^{2}$} \\
\hline & $\mathrm{C}$ & $\mathrm{CR}$ & CRFL & CRFS & SRFL & SRFS & & $\mathrm{R}$ & $\mathrm{F}$ & $\mathrm{CP}$ & PS & $\mathrm{CP} \times \mathrm{PS}$ \\
\hline $12: 0$ & 0.24 & 0.22 & 0.12 & 0.13 & 0.12 & 0.12 & 0.01 & $<0.01$ & $<0.01$ & 0.11 & 0.23 & 0.22 \\
\hline $14: 0$ & 1.23 & 1.18 & 0.64 & 0.66 & 0.62 & 0.63 & 0.04 & 0.26 & $<0.01$ & 0.40 & 0.58 & 0.81 \\
\hline $14: 1$ & 1.02 & 1.03 & 0.49 & 0.48 & 0.50 & 0.49 & 0.02 & 0.59 & $<0.01$ & 0.73 & 0.71 & 0.75 \\
\hline $16: 0$ & 13.7 & 14.4 & 13.7 & 13.6 & 13.5 & 13.4 & 0.10 & $<0.01$ & $<0.01$ & 0.09 & 0.75 & 0.98 \\
\hline $18: 1$ trans $-4,5$ & 0.090 & 0.098 & 0.102 & 0.096 & 0.118 & 0.102 & 0.009 & 0.43 & 0.63 & 0.13 & 0.13 & 0.49 \\
\hline $18: 1$ trans $-6,7,8$ & 0.058 & 0.070 & 0.072 & 0.072 & 0.079 & 0.071 & 0.007 & 0.19 & 0.83 & 0.59 & 0.53 & 0.48 \\
\hline $18: 1$ trans -9 & 0.43 & 0.53 & 1.05 & 1.08 & 1.04 & 1.01 & 0.12 & 0.46 & $<0.01$ & 0.65 & 0.98 & 0.73 \\
\hline $18: 1$ trans -10 & 1.17 & 1.45 & 4.99 & 4.74 & 5.05 & 4.70 & 1.12 & 0.83 & 0.01 & 0.99 & 0.74 & 0.95 \\
\hline $18: 1$ trans -11 & 2.49 & 2.75 & 3.78 & 3.96 & 3.98 & 3.85 & 0.53 & 0.72 & 0.18 & 0.93 & 0.96 & 0.77 \\
\hline $18: 1$ trans -12 & 0.53 & 0.65 & 0.79 & 0.78 & 0.82 & 0.76 & 0.04 & $<0.01$ & $<0.01$ & 0.75 & 0.20 & 0.31 \\
\hline 18:1 trans -15 & 0.44 & 0.55 & 0.50 & 0.49 & 0.53 & 0.49 & 0.03 & 0.02 & 0.31 & 0.63 & 0.39 & 0.60 \\
\hline $18: 1$ cis -15 & 0.068 & 0.086 & 0.139 & 0.140 & 0.136 & 0.137 & 0.015 & 0.26 & $<0.01$ & 0.82 & 0.92 & 0.98 \\
\hline $18: 2$ trans- 11, cis -15 & 0.21 & 0.25 & 0.26 & 0.28 & 0.28 & 0.27 & 0.02 & 0.07 & 0.79 & 0.75 & 0.68 & 0.19 \\
\hline $18: 2$ cis -9, cis -12 & 8.51 & 9.20 & 9.39 & 10.1 & 9.73 & 11.0 & 0.83 & 0.50 & 0.85 & 0.41 & 0.17 & 0.73 \\
\hline $18: 3 n-3$ & 1.14 & 1.27 & 1.17 & 1.23 & 1.23 & 1.33 & 0.09 & 0.29 & 0.39 & 0.35 & 0.35 & 0.82 \\
\hline CLA $^{3}$ cis- 9, trans- 11 & 0.36 & 0.32 & 0.79 & 0.74 & 0.83 & 0.79 & 0.15 & 0.85 & 0.02 & 0.77 & 0.74 & 0.95 \\
\hline CLA trans- 10, cis- 12 & 0.18 & 0.18 & 0.19 & 0.20 & 0.26 & 0.24 & 0.04 & 0.91 & 0.72 & 0.13 & 0.85 & 0.61 \\
\hline Total SMCFA ${ }^{4}$ & 27.8 & 26.8 & 20.6 & 20.2 & 20.0 & 20.2 & 0.39 & 0.03 & $<0.01$ & 0.39 & 0.64 & 0.35 \\
\hline Total trans 18:1 & 5.78 & 6.75 & 11.9 & 11.8 & 12.3 & 11.6 & 0.92 & 0.24 & $<0.01$ & 0.92 & 0.51 & 0.62 \\
\hline Total cis $18: 1$ & 6.84 & 7.60 & 8.20 & 8.52 & 8.61 & 8.69 & 0.46 & 0.11 & 0.21 & 0.38 & 0.54 & 0.71 \\
\hline Total LCFA $^{5} \geq 20 \mathrm{C}$ & 2.88 & 2.67 & 1.99 & 2.04 & 1.98 & 2.02 & 0.07 & 0.02 & $<0.01$ & 0.75 & 0.49 & 0.99 \\
\hline
\end{tabular}

${ }^{1} \mathrm{C}=$ control diet containing ground corn and long particle size of alfalfa hay (LAH); CR = C plus $12 \mathrm{~g} / \mathrm{t}$ of TMR DM of monensin as Rumensin $(\mathrm{R}) ; \mathrm{CRFL}=$ ground corn, $4 \%$ added fat $(\mathrm{F}), \mathrm{R}$, and LAH; CRFS = ground corn, $\mathrm{R}, \mathrm{F}$, and short particle size of alfalfa hay $(\mathrm{SAH})$; SRFL $=$ steam-flaked corn, R, F, and LAH; and SRFS = steam-flaked corn, R, F, and SAH.

${ }^{2} \mathrm{R}=$ effect of monensin addition ( $\mathrm{C}$ vs. $\mathrm{CR}$ ); $\mathrm{F}$ = effect of fat addition with monensin(CR vs. CRFL); CP = main effect of corn processing method (CRFL+CRFS vs. SRFL+SRFS); PS = main effect of hay particle size (CRFL+SRFL vs. CRFS+SRFS); CP $\times$ PS $=$ interaction of corn processing method and hay particle size (CRFL+SRFS vs. CRFS+SRFL).

${ }^{3} \mathrm{CLA}=$ conjugated linoleic acid.

${ }^{4}$ Short- and medium-chain FA.

${ }^{5}$ Long-chain FA.

18:2 in fermenter contents. Christensen et al. (1998) reported a decrease in extent of $\mathrm{BH}$ with addition of unsaturated F. However, Loor et al. (2004) reported that supplementation of $3 \%$ linseed oil increased $\mathrm{BH}$ of total $\mathrm{C}_{18} \mathrm{FA}$.

The addition of $\mathrm{R}$ had no effects on apparent totaltract nutrient digestibility (Table 8). The addition of $\mathrm{F}$ decreased the apparent total-tract digestibility of total FA and total $\mathrm{C}_{18} \mathrm{FA}$, whereas it tended to decrease the apparent total-tract digestibility of total $\mathrm{C}_{16} \mathrm{FA}$. Wu et al. (1991) observed a similar decrease in total-tract digestibility when comparing diets with 3 and $6 \%$ added F. Palmquist (1991) also reported decreased apparent FA digestibility with increasing intake of supplemental F.

Steam-flaking increased apparent total-tract starch digestibility compared with grinding. This is in agree- ment with several studies where the apparent total-tract digestibility of starch was increased by steam-flaking corn (Firkins et al., 2001). Increased total-tract starch digestibility with steam-flaking could be a result of increased ruminal and postruminal starch digestibility (Zinn et al., 2002). Steam-flaking also tended to increase apparent total-tract NDF digestibility. The effects of corn processing on NDF digestibility have been variable. Increased NDF digestibility for steam-flaked corn diets compared with ground corn diets is in agreement with previous studies (Aldrich et al., 1993; Theurer et al., 1999). However, others have reported decreased NDF digestibility with corn processing (Plascencia and Zinn, 1996) and others have reported no effect on NDF digestibility (Harvatine et al., 2002a). Increased starch availability tends to decrease ruminal NDF digestibility (Firkins et al., 2001), but total-tract NDF digestibility 
Table 7. Least squares means of fatty acid (FA) intake and biohydrogenation in dairy cows fed monensin in diets varying in supplemental fat, starch availability, and hay particle size

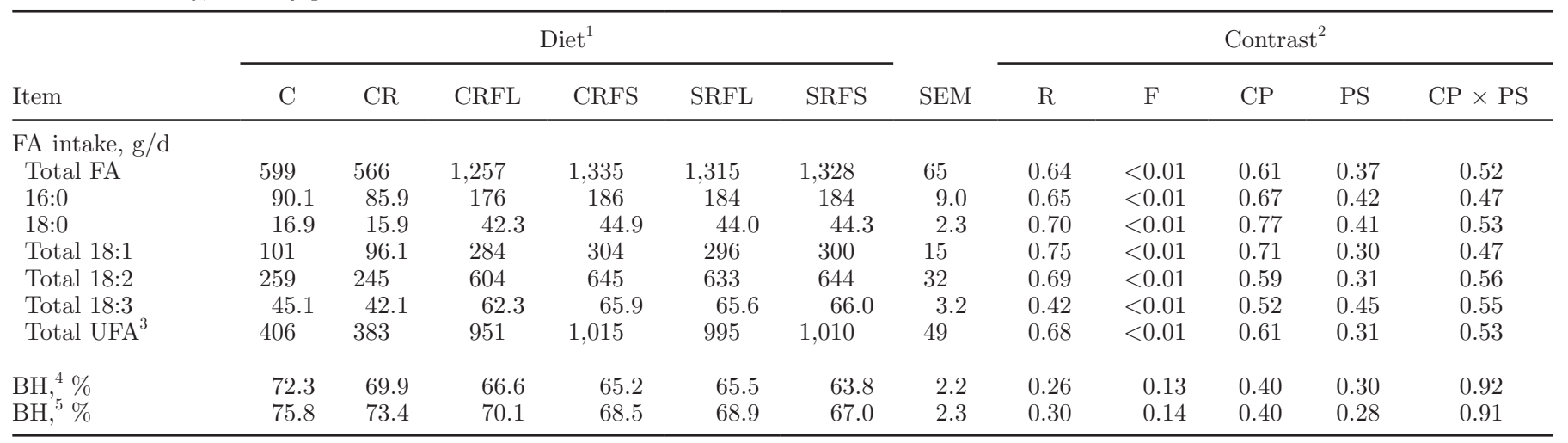

${ }^{1} \mathrm{C}=$ control diet containing ground corn and long particle size of alfalfa hay (LAH); CR = C plus $12 \mathrm{~g} / \mathrm{t}$ of TMR DM of monensin as Rumensin $(\mathrm{R}) ; \mathrm{CRFL}=$ ground corn, $4 \%$ added fat $(\mathrm{F}), \mathrm{R}$, and LAH; CRFS = ground corn, $\mathrm{R}, \mathrm{F}$, and short particle size of alfalfa hay $(\mathrm{SAH}) ; \mathrm{SRFL}=$ steam-flaked corn, R, F, and LAH; and SRFS = steam-flaked corn, R, F, and SAH.

${ }^{2} \mathrm{R}=$ effect of monensin addition ( $\mathrm{C}$ vs. $\mathrm{CR}$ ); $\mathrm{F}=$ effect of fat addition with monensin ( $\mathrm{CR}$ vs. CRFL); $\mathrm{CP}=$ main effect of corn processing method (CRFL+CRFS vs. SRFL+SRFS); PS = main effect of hay particle size $($ CRFL+SRFL vs. CRFS+SRFS); and CP $\times$ PS $=$ interaction of corn processing method and hay particle size (CRFL+SRFS vs. CRFS+SRFL).

${ }^{3}$ Unsaturated fatty acid.

${ }^{4}$ Biohydrogenation calculated using equation according to Tice et al. (1994), which accounted for the number of unsaturated bonds in each FA and included total 18:1 FA.

${ }^{5}$ Biohydrogenation calculated using the above equation, but accounting for only trans 18:1 FA instead of total 18:1 FA.

is often unaffected due to the intestinal digestibility of corn NDF. However, the lack of ruminal pH differences in our study could have allowed steam-flaked corn to maintain a favorable environment for fibrolytic organisms, whereas increasing overall carbohydrate availability. Steam-flaking decreased concentrations of ruminal isoacids (isovalerate and isobutyrate), which could be due to increased utilization of these acids. The cellulolytic bacteria require these isoacids as growth factors (Van Soest, 1994). Increased utilization of $\mathrm{NH}_{3} \mathrm{~N}$ with the steam-flaked diets could also help corroborate increased NDF digestibility as $\mathrm{NH}_{3}$ is considered a re- quirement for cellulolytic bacteria. On the other hand, Zinn et al. (2002) suggested that the improved totaltract digestibility of NDF with steam-flaking might be due to compensatory fiber digestion in the large intestine, possibly by reducing the amount of starch reaching the intestine and thus helping to maintain a cecal $\mathrm{pH}$ suitable for microbial fermentation of NDF in the large intestine.

The addition of $\mathrm{R}$ to the diets tended $(P=0.09)$ to decrease DMI (Table 9). This is consistent with some studies where feeding $\mathrm{R}$ decreased DMI, but this response could have been dose-dependent, especially in

Table 8. Least squares means for apparent total-tract nutrient digestibility (\%) in dairy cows fed monensin in diets varying in supplemental fat, starch availability, and hay particle size

\begin{tabular}{|c|c|c|c|c|c|c|c|c|c|c|c|c|}
\hline \multirow[b]{2}{*}{ Digestibility, \% } & \multicolumn{6}{|c|}{ Diet $^{1}$} & \multirow[b]{2}{*}{ SEM } & \multicolumn{5}{|c|}{ Contrast $^{2}$} \\
\hline & $\mathrm{C}$ & $\mathrm{CR}$ & CRFL & CRFS & SRFL & SRFS & & $\mathrm{R}$ & $\mathrm{F}$ & $\mathrm{CP}$ & PS & $\mathrm{CP} \times \mathrm{PS}$ \\
\hline DM & 70.4 & 71.2 & 71.9 & 70.3 & 74.2 & 73.0 & 1.9 & 0.73 & 0.75 & 0.14 & 0.39 & 0.91 \\
\hline $\mathrm{OM}$ & 72.2 & 72.9 & 73.6 & 71.9 & 75.8 & 74.5 & 1.9 & 0.73 & 0.77 & 0.13 & 0.33 & 0.91 \\
\hline NDF & 55.5 & 57.5 & 53.0 & 49.1 & 56.9 & 55.1 & 3.1 & 0.61 & 0.26 & 0.09 & 0.31 & 0.72 \\
\hline $\mathrm{N}$ & 69.8 & 71.6 & 71.6 & 70.9 & 74.6 & 73.5 & 2.4 & 0.49 & 1.00 & 0.15 & 0.63 & 0.93 \\
\hline Total $\mathrm{FA}^{3}$ & 79.5 & 81.1 & 73.5 & 73.7 & 76.6 & 76.0 & 2.0 & 0.52 & 0.01 & 0.13 & 0.91 & 0.83 \\
\hline Total C16 FA & 78.3 & 80.7 & 76.3 & 75.9 & 79.0 & 77.8 & 2.0 & 0.32 & 0.08 & 0.18 & 0.62 & 0.81 \\
\hline Total C18 FA & 83.4 & 84.6 & 74.2 & 74.7 & 77.4 & 77.0 & 2.1 & 0.63 & $<0.01$ & 0.14 & 0.98 & 0.81 \\
\hline Starch & 98.1 & 97.5 & 98.1 & 98.3 & 99.2 & 99.0 & 0.5 & 0.25 & 0.25 & 0.02 & 0.92 & 0.66 \\
\hline
\end{tabular}

${ }^{1} \mathrm{C}=$ control diet containing ground corn and long particle size of alfalfa hay (LAH); CR = C plus $12 \mathrm{~g} / \mathrm{t}$ of TMR DM of monensin as Rumensin $(\mathrm{R}) ; \mathrm{CRFL}=$ ground corn, $4 \%$ added fat $(\mathrm{F}), \mathrm{R}$, and LAH; CRFS = ground corn, R, F, and short particle size of alfalfa hay $(\mathrm{SAH}) ; \mathrm{SRFL}=$ steam-flaked corn, R, F, and LAH; and SRFS = steam-flaked corn, R, F, and SAH.

${ }^{2} \mathrm{R}=$ effect of monensin addition (C vs. CR); $\mathrm{F}=$ effect of fat addition with monensin (CR vs. CRFL); CP = main effect of corn processing method (CRFL+CRFS vs. SRFL+SRFS); PS = main effect of hay particle size $($ CRFL+SRFL vs. CRFS + SRFS $) ;$ and CP $\times$ PS $=$ interaction of corn processing method and hay particle size (CRFL+SRFS vs. CRFS+SRFL).

${ }^{3} \mathrm{FA}=$ fatty acid. 
Table 9. Least squares means for DMI, milk yield, and milk production for dairy cows fed monensin in diets varying in supplemental fat, starch availability, and hay particle size

\begin{tabular}{|c|c|c|c|c|c|c|c|c|c|c|c|c|}
\hline \multirow[b]{2}{*}{ Item } & \multicolumn{6}{|c|}{ Diet $^{1}$} & \multirow[b]{2}{*}{ SEM } & \multicolumn{5}{|c|}{ Contrast $^{2}$} \\
\hline & $\mathrm{C}$ & $\mathrm{CR}$ & CRFL & CRFS & SRFL & SRFS & & $\mathrm{R}$ & $\mathrm{F}$ & $\mathrm{CP}$ & PS & $\mathrm{CP} \times \mathrm{PS}$ \\
\hline $\mathrm{BW}, \mathrm{kg}$ & 683 & 672 & 675 & 671 & 676 & 678 & 19 & 0.21 & 0.67 & 0.52 & 0.82 & 0.63 \\
\hline BCS & 2.88 & 2.83 & 2.83 & 2.79 & 2.83 & 2.88 & 0.06 & 0.26 & 1.00 & 0.11 & 1.00 & 0.11 \\
\hline Milk yield, $\mathrm{kg} / \mathrm{d}$ & 36.1 & 33.8 & 33.6 & 35.1 & 33.8 & 36.1 & 3.7 & 0.20 & 0.91 & 0.59 & 0.12 & 0.73 \\
\hline $3.5 \% \mathrm{FCM}, \mathrm{kg} / \mathrm{d}$ & 35.1 & 31.8 & 29.9 & 32.5 & 31.2 & 32.0 & 3.1 & 0.07 & 0.30 & 0.75 & 0.19 & 0.46 \\
\hline Milk fat, $\mathrm{kg} / \mathrm{d}$ & 1.21 & 0.99 & 0.95 & 1.07 & 1.02 & 1.01 & 0.12 & 0.03 & 0.63 & 0.89 & 0.39 & 0.29 \\
\hline Milk protein, \% & 3.12 & 3.04 & 3.03 & 3.02 & 3.04 & 3.00 & 0.10 & 0.40 & 0.86 & 0.95 & 0.65 & 0.75 \\
\hline Milk protein, $\mathrm{kg} / \mathrm{d}$ & 1.11 & 1.02 & 1.01 & 1.05 & 1.02 & 1.07 & 0.10 & 0.15 & 0.88 & 0.70 & 0.22 & 0.87 \\
\hline Lactose, \% & 4.77 & 4.75 & 4.68 & 4.59 & 4.73 & 4.70 & 0.10 & 0.79 & 0.40 & 0.17 & 0.27 & 0.56 \\
\hline MUN, mg/dL & 12.8 & 13.9 & 11.5 & 11.3 & 12.0 & 11.3 & 0.7 & 0.09 & $<0.01$ & 0.59 & 0.29 & 0.55 \\
\hline
\end{tabular}

${ }^{1} \mathrm{C}=$ control diet containing ground corn and long particle size of alfalfa hay (LAH): $\mathrm{CR}=\mathrm{C}$ plus $12 \mathrm{~g} / \mathrm{t}$ of TMR DM of monensin as Rumensin $(\mathrm{R}) ; \mathrm{CRFL}=$ ground corn, $4 \%$ added fat $(\mathrm{F}), \mathrm{R}$, and LAH; CRFS = ground corn, R, F, and short particle size of alfalfa hay (SAH); SRFL = steam-flaked corn, R, F, and LAH; and SRFS = steam-flaked corn, R, F, and SAH.

${ }^{2} \mathrm{R}=$ effect of monensin addition (C vs. CR); $\mathrm{F}=$ effect of fat addition with monensin (CR vs. CRFL); CP = main effect of corn processing method (CRFL+CRFS vs. SRFL+SRFS); PS = main effect of hay particle size $(\mathrm{CRFL}+\mathrm{SRFL}$ vs. CRFS+SRFS); and CP $\times$ PS $=$ interaction of corn processing method and hay particle size (CRFL+SRFS vs. CRFS+SRFL).

trials where $\mathrm{R}$ dose exceeded $350 \mathrm{mg} / \mathrm{d}$ (Ipharraguerre and Clark, 2003). The average $\mathrm{R}$ dose in our study was about $317 \mathrm{mg} / \mathrm{d}$ or $15 \mathrm{mg} / \mathrm{kg}$ (Tables 1 and 9 ). Intake of DM was not different in the diets differing in hay particle size, even though the peNDF was reduced in the diets with SAH. Reducing the particle size of forages can increase DMI by increasing the density of the feed and allowing faster passage rate (Van Soest, 1994). Steam-flaking of corn also did not affect DMI. This is consistent with previous studies comparing diets with dry-rolled corn and steam-flaked corn (Santos et al., 1999).

Addition of $\mathrm{R}$ had no significant effect on milk yield (Table 9), although cows were in late lactation when less response to treatments would be expected compared with early or mid lactation. However, addition of $\mathrm{R}$ tended $(P=0.07)$ to decrease $3.5 \%$ FCM yield. Ipharraguerre and Clark (2003) reported that ionophores either had no effect or increased milk yield, whereas McGuffey et al. (2001) summarized 11 studies that reported higher milk yield for cows fed $\mathrm{R}$.

The $\mathrm{R}$ addition decreased $(P=0.03)$ milk fat yield and numerically lowered milk fat percentage. This is in agreement with the study by Sauer et al. (1998), who reported decreased milk fat yield and milk fat percentage as a result of feeding R. Phipps et al. (2000) and Odongo et al. (2007) also reported that $\mathrm{R}$ decreased milk fat percentage in TMR-fed cows. We did not observe any differences in milk fat percentage or yield with the addition of $\mathrm{F}$. An interaction $(P=0.10)$ between corn processing method and hay particle size on milk fat percentage was observed. The SAH tended to increase milk fat percentage for the ground corn diet, whereas it tended to decrease milk fat percentage with the steam-flaked diet.

Treatment did not affect milk protein percentage and yield. The $\mathrm{R}$ tended $(P=0.09)$ to increase MUN. A similar increase in MUN with R supplementation was observed by other researchers (Benchaar et al., 2006), who noted that $\mathrm{R}$ increases the amount of protein reaching the small intestine and use of amino acids for gluconeogenesis which increases deamination of amino acids and concentration of urea in blood. The addition of $\mathrm{F}$ with $\mathrm{R}$ decreased MUN, similar to the response observed by Rodriguez et al. (1997). Benchaar et al. (2006) reported that MUN increased with R supplementation, but did not see this effect when $\mathrm{R}$ was fed in combination with essential oils. The decline in MUN in our study was reflective of the decrease in ruminal $\mathrm{NH}_{3}$ $\mathrm{N}$ concentrations noted with $\mathrm{F}$ addition (Table 4).

Milk FA composition is shown in Table 10. Contrary to our expectation, the addition of $\mathrm{R}$ did not have a major effect on milk FA profile. The $\mathrm{R}$ did not affect the concentration of cis-9, trans-11 CLA or trans-10, cis-12 CLA. However, R decreased proportions of certain short and medium chain FA. Several researchers have reported changes in milk FA profile with $\mathrm{R}$ diets. AlZahal et al. (2008) reported that $\mathrm{R}$ reduced total short- and medium-chain FA and increased total trans 18:1, cis-9, trans-11 CLA, trans-10, cis-12 CLA and trans-10 18:1. In their study, the lowest concentration of ether extract in the diets compared was $5.4 \%$ and the $\mathrm{R}$ dose used was $22 \mathrm{mg} / \mathrm{kg}$ of DM.

The addition of $\mathrm{R}$ at a dose rate of $24 \mathrm{mg} / \mathrm{kg}$ to a basal diet containing $4.34 \%$ ether extract did not affect the milk FA profile (Bell et al., 2006). The trans-10, 
Table 10. Least squares means of fatty acid (FA) composition (\% of total FA) of milk fat of dairy cows fed monensin in diets varying in supplemental fat, starch availability, and hay particle size

\begin{tabular}{|c|c|c|c|c|c|c|c|c|c|c|c|c|}
\hline \multirow[b]{2}{*}{ FA } & \multicolumn{6}{|c|}{$\operatorname{Diet}^{1}$} & \multirow[b]{2}{*}{ SEM } & \multicolumn{5}{|c|}{ Contrast $^{2}$} \\
\hline & $\mathrm{C}$ & $\mathrm{CR}$ & CRFL & CRFS & SRFL & SRFS & & $\mathrm{R}$ & $\mathrm{F}$ & $\mathrm{CP}$ & PS & $\mathrm{CP} \times \mathrm{PS}$ \\
\hline 8:0 & 1.37 & 1.32 & 0.84 & 0.86 & 0.91 & 0.82 & 0.11 & 0.54 & $<0.01$ & 0.87 & 0.58 & 0.33 \\
\hline 10:0 & 3.44 & 3.24 & 1.80 & 1.87 & 1.98 & 1.76 & 0.26 & 0.27 & $<0.01$ & 0.75 & 0.51 & 0.23 \\
\hline $12: 0$ & 4.12 & 3.87 & 2.15 & 2.20 & 2.31 & 2.07 & 0.25 & 0.07 & $<0.01$ & 0.82 & 0.27 & 0.12 \\
\hline 18:0 & 9.11 & 9.25 & 12.7 & 12.1 & 13.5 & 12.3 & 0.82 & 0.83 & $<0.01$ & 0.21 & 0.05 & 0.50 \\
\hline $18: 1$ trans $-6,7,8$ & 0.24 & 0.26 & 0.73 & 0.68 & 0.74 & 0.70 & 0.10 & 0.86 & $<0.01$ & 0.81 & 0.54 & 0.95 \\
\hline 18:1 trans -9 & 0.18 & 0.19 & 0.47 & 0.44 & 0.50 & 0.46 & 0.05 & 0.85 & $<0.01$ & 0.54 & 0.38 & 0.85 \\
\hline $18: 1$ trans -10 & 0.47 & 0.66 & 2.90 & 2.63 & 2.89 & 2.84 & 0.78 & 0.84 & 0.03 & 0.87 & 0.79 & 0.86 \\
\hline $18: 1$ trans -11 & 0.79 & 1.00 & 2.21 & 2.39 & 2.40 & 2.26 & 0.38 & 0.71 & 0.04 & 0.92 & 0.95 & 0.66 \\
\hline $18: 1$ trans -12 & 0.33 & 0.36 & 0.66 & 0.58 & 0.67 & 0.65 & 0.05 & 0.53 & $<0.01$ & 0.25 & 0.13 & 0.33 \\
\hline $18: 1$ trans -15 & 0.17 & 0.19 & 0.36 & 0.34 & 0.38 & 0.35 & 0.01 & 0.24 & $<0.01$ & 0.17 & 0.08 & 0.74 \\
\hline $18: 1$ cis -15 & 0.11 & 0.14 & 0.19 & 0.17 & 0.19 & 0.18 & 0.01 & 0.14 & 0.01 & 0.90 & 0.22 & 0.82 \\
\hline $18: 2$ trans -11, cis -15 & 0.058 & 0.071 & 0.145 & 0.132 & 0.136 & 0.148 & 0.012 & 0.23 & $<0.01$ & 0.61 & 0.99 & 0.09 \\
\hline $18: 2$ cis- 9, cis -12 & 3.08 & 3.00 & 5.64 & 5.79 & 6.13 & 5.96 & 0.26 & 0.78 & $<0.01$ & 0.10 & 0.93 & 0.41 \\
\hline $18: 3 n-3$ & 0.36 & 0.37 & 0.68 & 0.72 & 0.71 & 0.73 & 0.03 & 0.71 & $<0.01$ & 0.32 & 0.14 & 0.48 \\
\hline $18: 3 n-6$ & 0.047 & 0.046 & 0.032 & 0.029 & 0.036 & 0.032 & 0.003 & 0.76 & $<0.01$ & 0.29 & 0.35 & 0.91 \\
\hline CLA $^{3}$ cis-9,trans -11 & 0.47 & 0.54 & 1.16 & 1.26 & 1.22 & 1.21 & 0.14 & 0.70 & $<0.01$ & 0.93 & 0.70 & 0.64 \\
\hline CLA trans- 10, cis- 12 & 0.016 & 0.021 & 0.043 & 0.041 & 0.038 & 0.044 & 0.010 & 0.69 & 0.08 & 0.93 & 0.82 & 0.60 \\
\hline Total SMCFA ${ }^{3}$ & 56.8 & 55.0 & 38.2 & 39.0 & 39.7 & 37.7 & 1.8 & 0.22 & $<0.01$ & 0.91 & 0.56 & 0.14 \\
\hline Total LCFA ${ }^{3}$ & 0.92 & 0.90 & 0.81 & 0.79 & 0.87 & 0.83 & 0.04 & 0.62 & 0.04 & 0.06 & 0.36 & 0.79 \\
\hline Total trans 18:1 & 2.48 & 2.95 & 7.83 & 7.53 & 8.10 & 7.76 & 0.77 & 0.54 & $<0.01$ & 0.63 & 0.54 & 0.97 \\
\hline Total cis $18: 1$ & 19.4 & 20.0 & 26.0 & 25.8 & 26.1 & 25.7 & 1.1 & 0.50 & $<0.01$ & 1.00 & 0.50 & 0.80 \\
\hline
\end{tabular}

${ }^{1} \mathrm{C}=$ control diet containing ground corn and long particle size of alfalfa hay (LAH); $\mathrm{CR}=\mathrm{C}$ plus $12 \mathrm{~g} / \mathrm{t}$ TMR DM of monensin as Rumensin $(\mathrm{R}) ; \mathrm{CRFL}=$ ground corn, $4 \%$ added fat $(\mathrm{F}), \mathrm{R}$, and LAH; CRFS = ground corn, R, F, and short particle size of alfalfa hay $(\mathrm{SAH}) ; \mathrm{SRFL}=$ steam-flaked corn, R, F, and LAH; and SRFS = steam-flaked corn, R, F, and SAH.

${ }^{2} \mathrm{R}=$ effect of monensin addition ( $\mathrm{C}$ vs. $\mathrm{CR}$ ); $\mathrm{F}=$ effect of fat addition with monensin (CR vs. CRFL); CP = main effect of corn processing method (CRFL+CRFS vs. SRFL+SRFS); PS = main effect of hay particle size $($ CRFL+SRFL vs. CRFS + SRFS $)$; and CP $\times$ PS $=$ interaction of corn processing method and hay particle size (CRFL+SRFS vs. CRFS+SRFL).

${ }^{3} \mathrm{CLA}=$ conjugated linoleic acid; SMCFA $=$ short- and medium-chain FA; and LCFA = long-chain FA.

cis-12 CLA was not detected in milk fat for the $\mathrm{R}$ treatment. In the study by Benchaar et al. (2006) in which $\mathrm{R}$ was fed at a dose rate of $16 \mathrm{mg} / \mathrm{kg}, \mathrm{R}$ did not affect short- and medium-chain FA in milk, whereas the concentrations of trans-10 18:1 and trans-11 18:1 were increased.

Addition of $\mathrm{F}$ with $\mathrm{R}$ decreased concentrations of short- and medium-chain FA. This apparent reduction in de novo-derived FA in milk with the addition of $\mathrm{F}$ has been reported in other studies (AbuGhazaleh et al., 2002; Whitlock et al., 2002). Bell et al. (2006) reported a similar reduction in the proportion of shortand medium-chain FA with a corresponding increase in trans 18:1, cis-9 18:1, and 18:2 (n-6) in milk fat of cows supplemented with $\mathrm{R}$ and $6 \%$ safflower oil. In the present study, the concentrations of 18:0; cis-9 18:1; cis-9, cis-12 18:2; cis-6, cis-9, cis-12 18:3; and cis-9, cis-12, cis-15 18:3 were increased with the addition of F. Fat increased total trans 18:1 and total cis 18:1 concentrations. The addition of $\mathrm{F}$ increased concentrations of cis-9, trans-11 CLA, similar to the response reported by Bell et al. (2006). Steam-flaking tended $(P=0.09)$ to increase concentrations of cis-9, cis-12 18:2. Concentration of 18:0 in milk fat decreased with SAH.

Milk fat depression is usually associated with changes in specific FA concentrations in milk, especially a decrease in de novo-synthesized FA and an increase in long-chain FA (Gaynor et al., 1995). Although we observed changes in milk FA profiles consistent with those reported in other studies with MFD for the added $\mathrm{F}$ to the $\mathrm{R}$ diet (Table 9), these changes were not as severe as sometimes observed in the field. Perhaps the source of added F, namely cracked roasted soybeans and distillers dried grains with solubles, led to a slow release of oil and decreased the rate of formation of $\mathrm{BH}$ intermediates. The milk FA profile for the added 
$\mathrm{F}$ diets was different from that of the $\mathrm{R}$ diets, in that even though there were lower proportions of short- and medium-chain FA compared with the $\mathrm{R}$ diets, this was compensated by the greater proportions of 18:0, trans-10 18:1, trans-11 18:1, and cis-9 18:1. These differences in FA for the added-F diets might be reflective of either an increased substrate supply and resultant increase in $\mathrm{BH}$ intermediates, or changes in the mammary gland, which led to higher incorporation of long-chain FA in triglyceride synthesis.

\section{CONCLUSIONS}

The addition of $\mathrm{R}$ resulted in MFD, which might have been due to accumulation of specific BH intermediates other than trans-10, cis-12 CLA. The addition of $\mathrm{F}$ to diets containing $\mathrm{R}$ did not further exacerbate MFD, which might have been due to the source of supplemental $\mathrm{F}$ used in the present experiment, a blend of cracked, roasted soybeans and distillers dried grains with solubles. An interaction between corn processing and hay particle size on milk fat percentage was observed, with the steam-flaked corn diets resulting in greater MFD with SAH. This effect could not be attributed to a specific $\mathrm{BH}$ intermediates in either the rumen contents or milk.

\section{REFERENCES}

AbuGhazaleh, A. A., D. J. Schingoethe, A. R. Hippen, K. F. Kalscheur, and L. A. Whitlock. 2002. Fatty acid profiles of milk and rumen digesta from cows fed fish oil, extruded soybeans or their blend. J. Dairy Sci. 85:2266-2276.

Aldrich, J. M., L. D. Muller, G. A. Varga, and L. C. Griel Jr.. 1993 Nonstructural carbohydrate and protein effects on rumen fermentation, nutrient flow, and performance of dairy cows. J. Dairy Sci. 76:1091-1105.

AlZahal, O., N. E. Odongo, T. Mutsvangwa, M. M. Or-Rashid, T. F. Duffield, R. Bagg, P. Dick, G. Vessie, and B. W. McBride. 2008 Effects of monensin and dietary soybean oil on milk fat percentage and milk fatty acid profile in lactating dairy cows. J. Dairy Sci. 91:1166-1174.

AOAC. 1990. Official Methods of Analysis. Vol. I. 15th ed. Association of Official Analytical Chemists, Arlington, VA.

Bell, J. A., J. M. Griinari, and J. J. Kennelly. 2006. Effect of safflower oil, flaxseed oil, monensin, and vitamin E on concentration of conjugated linoleic acid in bovine milk fat. J. Dairy Sci. 89:733-748.

Benchaar, C., H. V. Petit, R. Berthiaume, T. D. Whyte, and P. Y. Chouinard. 2006. Effects of addition of essential oils and monensin premix on digestion, ruminal fermentation, milk production, and milk composition in dairy cows. J. Dairy Sci. 89:4352-4364.

Bernard, J. K., P. T. Chandler, J. W. West, A. H. Parks, H. A. Amos, M. A. Froetschel, and D. S. Trammell. 2004. Effect of supplemental L-lysine-HCL and corn source on rumen fermentation and amino acid flow to the small intestine. J. Dairy Sci. 87:399-405.

Broderick, G. A. 2004. Effect of low level monensin supplementation on the production of dairy cows fed alfalfa silage. J. Dairy Sci. $87: 359-368$.
Chaney, A. L., and E. P. Marbach. 1962. Modified reagents for determination of urea and ammonia. Clin. Chem. 8:130-132.

Christensen, R. A., J. H. Clark, J. K. Drackley, and S. A. Blum. 1998. Fatty acid flow to the duodenum and in milk from cows fed diets that contained fat and nicotinic acid. J. Dairy Sci. 81:10781088.

Dado, R. G., and M. S. Allen. 1995. Intake limitations, feeding behavior, and rumen function of cows challenged with rumen fill from dietary fiber or inert bulk. J. Dairy Sci. 78:118-133.

Doreau, M., and A. Ferlay. 1995. Effect of dietary lipids on nitrogen metabolism in the rumen: A review. Livest. Prod. Sci. 43:97110.

Duffield, T., R. Bagg, D. Kelton, P. Dick, and J. Wilson. 2003. A field study of dietary interactions with monensin on milk fat percentage in lactating dairy cattle. J. Dairy Sci. 86:4161-4166.

Duffield, T. F., A. R. Rabiee, and I. J. Lean. 2008. A meta-analysis of the impact of monensin in lactating dairy cattle. Part 2. Production effects. J. Dairy Sci. 91:1347-1360.

Edmonson, A. J., I. J. Lean, L. D. Weaver, T. Farver, and G. Webster. 1989. A body condition scoring chart for Holstein dairy cows. J. Dairy Sci. 72:68-78.

Elliott, J. P., J. K. Drackley, C. G. Aldrich, and N. R. Merchen. 1997. Effects of saturation and esterification of fat sources on site and extent of digestion in steers: Ruminal fermentation and digestion of organic matter, fiber, and nitrogen. J. Anim. Sci. 75:2803-2812.

Fellner, V., F. D. Sauer, and J. K. G. Kramer. 1997. Effect of nigericin, monensin, and tetronasin on biohydrogenation in continuous flowthrough ruminal fermenters. J. Dairy Sci. 80:921-928.

Fievez, V., B. Vlaeminck, T. Jenkins, F. Enjalbert, and M. Doreau. 2007. Assessing rumen biohydrogenation and its manipulation in vivo, in vitro and in situ. Eur. J. Lipid Sci. Technol. 109:740756.

Firkins, J. L., M. L. Eastridge, N. R. St-Pierre, and S. M. Noftsger. 2001. Effects of grain variability and processing on starch utilization by lactating dairy cattle. J. Anim. Sci. 79(E. Suppl.):E218E238.

Gaynor, P. J., D. R. Waldo, A. V. Capuco, R. A. Erdman, L. W. Douglass, and B. B. Teter. 1995. Milk fat depression, the glucogenic theory, and trans-C18:1 fatty acids. J. Dairy Sci. 78:2008-2015.

Guan, H., K. M. Wittenberg, K. H. Ominski, and D. O. Krause. 2006. Efficacy of ionophores in cattle diets for mitigation of enteric methane. J. Anim. Sci. 84:1896-1906.

Harfoot, C. G., and G. P. Hazlewood. 1997. Lipid metabolism in the rumen. Pages 382-426 in The Rumen Microbial Ecosystem. P. N. Hobson and C. S. Stewart, ed. Chapman and Hall, New York, NY.

Harvatine, D. I., J. L. Firkins, and M. L. Eastridge. 2002a. Whole linted cottonseed as a forage substitute fed with ground or steamflaked corn: Digestibility and performance. J. Dairy Sci. 85:19761987.

Harvatine, D. I., J. E. Winkler, M. Devant-Guille, J. L. Firkins, N. R. St-Pierre, B. S. Oldick, and M. L. Eastridge. 2002b. Whole linted cottonseed as a forage substitute: Fiber effectiveness and digestion kinetics. J. Dairy Sci. 85:1988-1999.

Ipharraguerre, I., and J. Clark. 2003. Usefulness of ionophores for lactating dairy cows: A review. Anim. Feed Sci. Technol. 106:3957.

Jenkins, T. C., V. Fellner, and R. K. McGuffey. 2003. Monensin by fat interactions on trans fatty acids in cultures of mixed ruminal microorganisms grown in continuous fermentors fed corn or barley. J. Dairy Sci. 86:324-330.

Karkalas, J. J. 1985. An improved enzymatic method for the determination of native and modified starch. J. Sci. Food Agric. 36:1019-1027.

Karnati, S. K. R., J. Sylvester, C. V. D. M. Ribeiro, L. Gilligan, and J. L. Firkins. 2009. Investigating unsaturated fat, monensin, or bromoethanesulfonate in continuous cultures retaining ruminal protozoa. I. Fermentation, biohydrogenation, and microbial protein synthesis. J. Dairy Sci. 92:3849-3860. 
Kononoff, P. J., A. J. Heinrichs, and D. R. Buckmaster. 2003. Modification of the Penn State forage and total mixed ration particle separator and the effects of moisture content on its measurements. J. Dairy Sci. 86:1858-1863.

Kramer, J. K. G., M. Hernandez, C. Cruz-Hernandez, J. Kraft, and M. E. R. Dugan. 2008. Combining results of two GC separations partly achieves determination of all cis and trans 16:1, 18:1, 18:2 and 18:3 except CLA isomers of milk fat as demonstrated using Ag-ion SPE fractionation. Lipids 43:259-273.

Loor, J. J., K. Ueda, A. Ferlay, Y. Chilliard, and M. Doreau. 2004. Biohydrogenation, duodenal flow, and intestinal digestibility of trans fatty acids and conjugated linoleic acids in response to dietary forage:concentrate ratio and linseed oil in dairy cows. J. Dairy Sci. 87:2472-2485.

Mathew, B. 2008. Interactions of monensin with dietary fat and carbohydrate components on ruminal fermentation and production responses by dairy cows. MS Thesis. The Ohio State University, Columbus.

McGuffey, R. K., L. F. Richardson, and J. I. D. Wilkinson. 2001. Ionophores for dairy cattle: Current status and future outlook. J. Dairy Sci. 84(E Suppl.):E194-E203.

Mendoza, G. D., R. A. Britton, and R. A. Stock. 1993. Influence of ruminal protozoa on site and extent of starch digestion and ruminal fermentation. J. Anim. Sci. 71:1572-1578.

Mertens, D. R. 1997. Creating a system for meeting the fiber requirements of dairy cows. J. Dairy Sci. 80:1463-1481.

Murphy, M. R., and J. S. Zhu. 1997. A comparison of methods to analyze particle size as applied to alfalfa haylage, corn silage, and concentrate mix. J. Dairy Sci. 80:2932-2938.

NRC. 2001. Nutrient Requirements of Dairy Cattle. 7th rev. ed. Natl. Acad. Sci., Washington, DC.

Odongo, N. E., M. M. Or-Rashid, R. Bagg, G. Vessie, P. Dick, E. Kebreab, J. France, and B. W. McBride. 2007. Long-term effects of feeding monensin on milk fatty acid composition in lactating dairy cows. J. Dairy Sci. 90:5126-5133.

Oldick, B. S., and J. L. Firkins. 2000. Effects of degree of fat saturation on fiber digestion and microbial protein synthesis when diets are fed twelve times daily. J. Anim. Sci. 78:2412-2420.

Palmquist, D. L. 1991. Influence of source and amount of dietary fat on digestibility in lactating cows. J. Dairy Sci. 74:1354-1360.

Palmquist, D. L., and T. C. Jenkins. 2003. Challenges with fats and fatty acid methods. J. Anim. Sci. 81:3250-3254.

Perfield, J. W. II, P. Delmonte, A. L. Lock, M. P. Yurawecz, and D. E. Bauman. 2006. Trans-10, trans-12 conjugated linoleic acid does not affect milk fat yield but reduces delta9-desaturase index in dairy cows. J. Dairy Sci. 89:2559-2566.

Peterson, D. G., E. A. Matitashvili, and D. E. Bauman. 2003. Diet-induced milk fat depression in dairy cows results in increased trans-10, cis-12 CLA in milk fat and coordinate suppression of mRNA abundance for mammary enzymes involved in milk fat synthesis. J. Nutr. 133:3098-3102.

Phipps, R. H., J. I. D. Wilkinson, L. J. Jonker, M. Tarrant, A. K. Jones, and A. Hodge. 2000. Effect of monensin on milk production of Holstein-Friesian dairy cows. J. Dairy Sci. 83:2789-2794.

Plascencia, A., and R. A. Zinn. 1996. Influence of flake density on the feeding value of steam-processed corn in diets for lactating cows. J. Anim. Sci. 74:310-316.
Ribeiro, C. V. D. M., S. K. R. Karnati, and M. L. Eastridge. 2005. Biohydrogenation of fatty acids and digestibility of fresh alfalfa or alfalfa hay plus sucrose in continuous culture. J. Dairy Sci. 88:4007-4017.

Robertson, J. B., and P. J. Van Soest. 1981. The detergent system of analysis and its application to human foods. Page 123 in The Analysis of Dietary Fiber in Food. W. P. T. James and P. Theander, ed., Marcel Dekker, Inc., New York, NY.

Rodriguez, L. A., C. C. Stallings, J. H. Herbein, and M. L. Mcgilliard. 1997. Diurnal variation in milk and plasma urea nitrogen in Holstein and Jersey cows in response to degradable dietary protein and added fat. J. Dairy Sci. 80:3368-3376.

Santos, J. E. P., J. T. Huber, C. B. Theurer, L. G. Nussio, M. Tarazon, and F. A. P. Santos. 1999. Response of lactating dairy cows to steam-flaked sorghum, steam-flaked corn, or steam-rolled corn and protein sources of differing degradability. J. Dairy Sci. 82:728737.

SAS Institute. 2004. SAS/STAT 9.1 User's Guide. SAS Inst. Inc. Cary, NC.

Sauer, F. D., V. Fellner, R. Kinsman, J. K. Kramer, H. A. Jackson, A. J. Lee, and S. Chen. 1998. Methane output and lactation response in Holstein cattle with monensin or unsaturated fat added to the diet. J. Anim. Sci. 76:906-914.

Theurer, C. B., J. T. Huber, A. Delgado-Elorduy, and R. Wanderley. 1999. Invited review: Summary of steam-flaking corn or sorghum grain for lactating dairy cows. J. Dairy Sci. 82:1950-1959.

Tice, E. M., M. L. Eastridge, and J. L. Firkins. 1994. Raw soybeans and roasted soybeans of different particle sizes. 2. Fatty acid utilization by lactating cows. J. Dairy Sci. 77:166-180.

Van Soest, P. J. 1994. Nutritional Ecology of the Ruminant. Cornell University Press, Ithaca, NY.

Van Soest, P. J., J. B. Robertson, and B. A. Lewis. 1991. Methods for dietary fiber, neutral detergent fiber, and nonstarch polysaccharides in relation to animal nutrition. J. Dairy Sci. 74:3583-3597.

Whitlock, L. A., D. J. Schingoethe, A. R. Hippen, K. F. Kalscheur, R. J. Baer, N. Ramaswamy, and K. M. Kasperson. 2002. Fish oil and extruded soybeans fed in combination increase conjugated linoleic acids in milk of dairy cows more than when fed separately. J. Dairy Sci. 85:234-243.

Williams, C. H., D. J. David, and O. Iismaa. 1962. The determination of chromic oxide in faeces samples by atomic absorption spectrophotometry. J. Agric. Sci. 59:381-385.

Wu, Z., O. A. Ohajuruka, and D. L. Palmquist. 1991. Ruminal synthesis, biohydrogenation, and digestibility of fatty acids by dairy cows. J. Dairy Sci. 74:3025-3034.

Yang, C. M., and J. B. Russell. 1993. The effect of monensin supplementation on ruminal ammonia accumulation in vivo and the numbers of amino acid-fermenting bacteria. J. Anim. Sci. 71:3470-3476.

Yang, W. Z., and K. A. Beauchemin. 2006. Effects of physically effective fiber on chewing activity and ruminal $\mathrm{pH}$ of dairy cows fed diets based on barley silage. J. Dairy Sci. 89:217-228.

Zinn, R. A., F. N. Owens, and R. A. Ware. 2002. Flaking corn: Processing mechanics, quality standards, and impacts on energy availability and performance of feedlot cattle. J. Anim. Sci. 80:11451156 . 